Jurnal IImiah AL-Jauhari (JIAJ)

Volume 3 No 1, Juni 2018

ISSN: $2541-3430$

E-ISSN: $2541-3449$

Halaman 97-138

\title{
Hubungan Persepsi Guru PAI terhadap Pendidikan Agama Islam Berbasis ICT dalam Meningkatkan Kualitas Pendidikan di-Era Masyarakat Ekonomi Asean (MEA) di Kota Gorontalo
}

\author{
Oleh: Rustam Hasyim \\ (Guru SMK Negeri 5 Kota Gorontalo)
}

\begin{abstract}
Abstrak
Membangun persepsi guru PAI terhadap pendidikan agama Islam berbasis ICT di-era Masyarakat Ekonomi Asean (MEA) merupakan suatu varian yang mempengaruhi dalam meningkatkan kualitas pendidikan agama Islam berbasis ICT di Kota Gorontalo. Metode penelitian menggunakan analisis data kombinasi (MixedMethods) dengan model Squential Explanatory Design, penelitian ini bertujuan untuk mendeskripsikan hasil penelitian kuantitatif pada tahap pertama dan memperluas, memperdalam serta membuktikan data kuantitatif dengan data kualitatif pada tahap kedua. Hasil temuan dalam penelitian ini mendeskripsikan bahwa (1) kualitas pendidikan agama Islam berbasis ICT di Kota Gorontalo diperoleh nilai porsentasi sebesar $=85,6 \%$, (2) persepsi guru PAI terhadap pendidikan agama Islam berbasis ICT diperoleh nilai porsentasi sebesar $=80,9 \%$. (3) terdapat hubungan yang signifikansi antara persepsi guru PAI terhadap pendidikan agama Islam berbasis ICT dengan peningkatan kualitas pendidikan dengan tingkat korelasi mencapai 98,6\%. Perbandingan data kuantitatif dan kualitatf secara keseluruhan menyimpulkan bahwa persepsi guru PAI terhadap pendidikan agama Islam berbasis ICT dalam meningkatkan kualitas pendidikan (PAI berbasis merupakan varian/faktor yang mempengaruhi sikap dan pengetahuan guru PAI dalam menentukan upaya untuk meningkatkan kualitas pendidikan di-era MEA.
\end{abstract}

Kata Kunci: Persepsi Guru PAI, Kualitas Pendidikan agama Islam berbasis ICT

\section{Pendahuluan}

Perkembangan dunia pendidikan dan kemajuan teknologi pendidikan yang canggih saat ini, memicu seluruh elemen masyarakat, bangsa dan Negara, untuk saling berkompetisi dalam meraih pendidikan yang bermutu dan berkompetensi. Dengan bergulirnya pendidikan bermutu dalam dunia pendidikan global saat ini, menuntut pengelola pendidikan untuk mampu merancang suatu program dan pengalaman belajar yang tepat dan berkualitas, sehingga pendidikan yang 
diharapkan dapat mencapai proses belajar yang effekif, unggul dan berkompetensi.

Aktivitas dan tindakan-tindakan pendidikan, serta tujuan strategis untuk mencapai pendidikan yang berkualitas diwujudkan dan dikembangkan oleh pemerintah melalui sekolah dan institusi pendidikan sebagai sasaran utama untuk mencapai pendidikan yang bermutu tinggi guna mewujudkan tujuan pendidikan diera global saat ini. Tujuan pendidikan diera globalisasi tercermin dari program pendidikan pemerintah yang diwujudkan dalam tujuan strategis pedidikan yaitu: (1) belajar sepanjang hayat, (2) mengadakan pelatihan dan pengembangan sumber daya manusia, (3) mendorong inovasi, (4) pengembangan teknologi informasi dan komunikasi (TIK), ilmu pengetahuan, dan teknologi terapan (IPTEK) dalam seluruh kegiatan pendidikan dan aspek lainnya.

Berdasarkan data Education For All (EFA) Global Monitoring Report, UNESCO tahun 2012, pendidikan Indonesia berada pada peringkat ke-64 dari 120 negara. Pada 2011, data Education Development Index (EDI) Indonesia mencapai 0,93. Nilai ini menempatkan Indonesia di posisi ke-69 dari 127 negara di dunia. Education Development Index (EDI) dikatakan tinggi bila mencapai 0,95-1. Kategori medium berada di atas 0,80, sedangkan kategori rendah di bawah 0,80.

Sementara itu, Laporan United Nations Depelopment Programme (UNDP), mencatat, IPM (Indeks Pembangunan Manusia) Indonesia tahun 2013 masih berada pada peringkat 108 dari 287 negara yang disurvei, dengan nilai IPM 0,684. Sedangkan Brunei Darussalam di perigkat 30 (IPM: 0,852). Singapura peringkat 9 (IPM: 0,901. Total nilai EDI itu diperoleh dari rangkuman perolehan empat kategori penilaian, yaitu angka partisipasi pendidikan dasar, angka melek huruf pada usia 15 tahun ke atas, angka partisipasi menurut kesetaraan gender, dan angka bertahan siswa hingga kelas lima sekolah dasar (SD). Rata-rata lama sekolah penduduk Indonesia hanya mencapai 7,5 tahun. Hal ini menunjukkan penduduk Indonesia yang berumur 15 tahun ke atas sebagian besar hanya menamatkan pendidikan sekolah dasar (SD/6 tahun). Pada tingkat Asia, pendidikan Indonesia masih tertinggal dari Brunei Darussalam yang berada di peringkat ke-34. Sementara Jepang berada di posisi nomor satu Asia. Malaysia berada di peringkat ke-65, Filipina (85),Kamboja (102), India (107), dan Laos (109).

Berdasarkan laporan tersebut, permasalahan pendidikan di Indonesia saat ini menimbulkan berbagai macam persepsi orang, sehingga memunculkan suatu pertanyaan, apakah yang harus dilakukan oleh para pendidik, siswa, tenaga kependidikan serta institusi pendidikan, untuk dapat memposisikan diri dalam persaingan dunia pendidikan dengan Negera-negara ASEAN lainya?

Trend pendidikan diera Masyarakat Ekonomi Asean (MEA) saat ini memicu berbagai macam asumsi serta kegelisahan-kegelisahan, yang dirasakan oleh dunia pendidikan. Perubahan-perubahan kebijakan yang terjadi dalam dunia pendidikan yang dilakukan oleh pemerintah, semata-mata untuk mempercepat kemajuan pendidikan itu sendiri, akan tetapi akibat (effect) dari perubahan kebijakan tersebut, dapat dirasakan oleh siswa, pendidik, tenaga kependidikan dan institusi pendidikan, mendorong untuk segera memperbaharui sistem penyelenggaraan 
pendidikan yang konvensional menuju sistem pendidikan yang modern dan berkompetensi.

Pro-kontra dengan kehadiran Masyarakat Ekonomi Asean (MEA) di tahun 2015-2016 menjadi suatu permasalahan global dalam bidang ekonomi, dan khususnya dalam dunia pendidikan saat ini. Pemikiran dan pembahasan pendidikan merupakan suatu agenda para cendikiawan dan para ahli yang dilakukan untuk mengkaji dan meneliti, bagaimana akibat (effect) dari trend Masyarakat Ekonomi Asean (MEA) terhadap dunia pendidikan saat ini, utamanya yang berhubungan dengan pendidikan berbasis ICT.

Kemajuan Teknologi Informasi dan Komunikasi (ICT) saat ini, mendorong dunia pendidikan untuk selalu merespon seluruh aktivitas pendidikan berbasis teknologi, sebagai obyek dari kemajuan Teknologi Informasi dan Komunikasi (ICT). Penggunaan ICT pada seluruh aktivitas kehidupan merupakan barometer utama bagi individu, sekelompok orang, bangsa dan Negara, untuk memposisikan diri sebagai individu, atau kelompok dan bangsa yang telah memiliki pendidikan dan peradaban yang modern. Kemajuan dan kecanggihan teknologi merupakan suatu fenomena yang tidak terelakkan di dunia pendidikan saat ini. Kebijakan pemerintah Indonesia dalam pendidikan berbasis Teknologi Informasi dan Komunikasi (ICT) telah diupayakan semaksimal mungkin, untuk mempersiapkan dan membekali para pendidik, siswa, tenaga pendidikan serta masyarakat umumnya, agar tidak melek dalam menggunakan Teknologi Informasi dan Komunikasi (ICT).

Rendahnya hasil belajar siswa di Kota Gorontalo tercermin dari hasil capain Ujian Nasional siswa. Hampir disemua bidang studi yang diujikan dalam Ujian Nasional berbasis Komputer (UNBK), pada jenjang SLTA belum memperlihatkan kenaikan hasil belajar siswa yang berarti dari standar ujian nasional yang diharapkan dengan nilai ketuntasan lulusan minimal $=5,5$ s.d 6,0. Hal ini dapat dilihat dari perbandingan hasil Ujian Nasional (UN) pada tahun 2014, 2015, 2016 untuk siswa SLTA/SMK se Kota Gorontalo.

Selain hasil belajar siswa pada ujian nasional yang masih relatif rendah, faktor luar yang mempengaruhi adalah faktor guru yang yang belum secara maksimal memanfaatkan dan menggunakan ICT pada proses pembelajaran dikelas, permasalahan ini tercermin dari: (1) sikap dan perilaku guru dalam proses pembelajaran. Sikap guru yang acuh tak acuh terhadap perkembangan ICT pendidikan saat ini mempengaruhi kualitas pendidikan khususnya pada model pendidikan berbasis ICT, (2) guru belum merasa tertantang untuk mengembangkan ICT sebagai media yang berkualitas baik dalam proses pembelajaran, sementara ini guru masih mengajar secara konvensional dengan menerapkan metode ceramah dan diskusi saja. (3) fator luar lainnya yang sangat esensial yaitu; penyediaaan fasilitas pendidikan berbasis ICT belum merata pada sekolah-sekolah secara keseluruhan serta (4) persepsi guru terhadap proses pembelajaran berbasis ICT yang masih relative rendah dalam memberikan sikap, pengetahuan dan pandangan.

Untuk mengembangkan dan membangun system pendidikan yang syarat dengan kualitas pendidikan yang handal dan berorentasi teknologi ICT dalam pendidikan, maka dibutuhkan peran pemerintah, orang tua dan sekolah, dalam hal 
meningkatkan dan mengembangkan kurikulum pendidikan berbasis ICT di sekolah Kota Gorontalo. Seiring dengan kemajuan ICT dalam pendidikan saat ini, diharapkan pendidikan dimaksud tidak melepaskan atribut-atribut sebagai manusia yang memiliki nilai-nilai budaya, norma dan ajaran agama. Oleh karenanya pendidikan berbasis ICT perlu dibarengi dengan pendidikan yang mengajarkan nilai-nilai dan ajaran agama, karena pendidikan agama merupakan salah satu pendidikan yang dapat mencegah pengaruh negatif terhadap perkembangan Teknologi Informasi dan Komunikasi (ICT) yang dialami oleh sekolah, guru, siswa dan masyarakat.

Menurut Nurcholish Madjid, bahwa pendidikan agama sesungguhnya adalah pendidikan untuk pertumbuhan total bagi seseorang, tidak benar jika pendidikan agama hanya dibatasi pada pengertian-pengetian yang konvensional dalam masyarakat. Meskipun pendidikan agama dalam masyarakat tidak seluruhnya salah, hal ini sangat jelas karena ada sebagian besar pengertian pendidikan agama yang baik dan harus dipertahankan menghadapi perubahan waktu dan jaman, dan ada juga sebagian besar pengertian-pengertian yang harus disempurnakan lagi untuk memaknai gejala-gejala yang terjadi oleh perubahan waktu, kondisi dan jaman.

Sudut pandang atau persepsi orang tentang pendidikan agama Islam saat ini lebih mengarah kepada pengembangan pendidikan yang mencerminkan kualitas pengelolaan pendidikan yang berbasis ICT. Olehnya untuk menghadapi dunia pendidikan diera Masyarakat Ekonomi Asean (MEA) saat ini, perlu dibangun kembali persepsi guru terhadap kualitas atau mutu dari pendidikan berbasis ICT itu sendiri. Bagaimana guru menunjukkan sikap dan pengetahuannya dalam merespon peningkatan kualitas pendidikan, khususnya pada pendidikan agama Islam berbasis ICT saat ini

Berdasarkan hasil pengamatan awal peneliti, dibeberapa sekolah di Kota Gorontalo diantaranya; SMK Negeri 1, SMK Negeri 5, SMP Negeri 1, SMP Negeri 6, dan SMA Negeri 2 serta dibeberapa Sekolah Dasar. Peneliti menemukan proses pendidikan agama Islam berbasis ICT yang dilaksanakan di sekolah masih belum effektif dan mencerminkan kualitas pelayanan dan pengelolaan pedidikan yang diharapkan di-era pendidikan berbasis ICT saat ini, serta sikap guru PAI dalam memberikan persespsi atau sudut pandang yang belum mengarah kepada pelayanan pendidikan agama Islam berbasis ICT yang diharapkan diera pendidikan yang ada dalam Masyarakat Ekonomi Asean (MEA). Sehingga dipandang perlu bagi peneliti untuk mengetahui seberapa besar pelaksanaan kualitas atau kualitas pendidikan agama Islam berbasis ICT yang diselenggarakan oleh pihak sekolah di Kota Gorontalo dan seberapa baik persepsi yang muncul dari guru PAI terhadap pendidikan agama Islam berbasis ICT diera-Masyarakat Ekonomi Asean (MEA) saat ini

\section{Pengembangan Teori Dan Hipotesis}

\section{A. MEA Dalam Komunitas ASEAN.}

ASEAN (Association of Southeast Asian Nations) atau Asosiasi BangsaBangsa Asia Tenggara adalah organisasi kawasan yang mewadahi kerjasama antar negara-negara di Asia Tenggara. Keinginan yang sama diantara negara Asean 
untuk memperbaiki pertumbuhan ekonomi, perkembangan social budaya serta perdamaian dan stabilitas dikawasan Asean melatarbelakangi para pemimpin ASEAN untuk menandatangi deklarasi Bangkok.

Beradasarkan Deklarasi Bangkok, pada tanggal 8 Agustus 1967 ASEAN didirikan oleh lima Negara pemrakarsa, yaitu Indonesia, Malaysia, Filipina, Singapura, dan Thailand, yang ditandai dengan penandatanganan Deklarasi Bangkok. Adapun tujuan ASEAN dalam penandatanganan Deklarasi Bangkok tersebut antara lain; untuk memelihara peradamaian, keamanan dan stabilitas dikawasan ASEAN, serta meningkatkan kesejahteraan bagi bangsa di Asia Tenggara melalui pembangunan dan kerja sama dibidang ekonomi dan sosial budaya.

Dalam buku "Ayo kita kenali ASEAN" bahwa prinsip-prinsip pembentukan ASEAN dimuat dalam piagam ASEAN diantaranya membahas tentang; menghormati kemerdekaan, kedaulatan, kesetaraan, integritas wilayah, dan identitas nasional diseluruh negara anggota ASEAN. Selanjutnya dalam prinsip tersebut diutamakan komitmen bersama dalam meningkatkan perdamaian, keamanan, serta kemakmuran dengan menolak seluruh agresi, ancaman penggunaan kekuatan atau tindakan lainnya dalam bentuk apapun yang bertentangan dengan hukum internasional. Selalu mengedepankan perdamaian dan tidak ikut mencampuri urusan dalam negeri di negara anggota ASEAN,menghormati setiap kebebasan yang mendasar dan memberikan perlindungan hak asasi manusia untuk keadilan social. Diberlakukannya piagam ASEAN secara effektif, hal ini sebagai upaya untuk menjalankan kerangka hukum dan kelembagaan yang mengikat bagi seluruh negara anggota ASEAN, sehingga negara anggota ASEAN memiliki status hukum (legal Personality) yang diakui oleh internasional. Piagam ASEAN tersebut, ditandatangani pada KTT ke-13 ASEAN tanggal 20 November tahun 2007 di Singapura oleh sepuluh kepala negara di negara anggota ASEAN. Secara effektif piagam ASEAN tersebut mulai diberlakukan pada tanggal 15 Desember tahun 2008. Indonesia melegitimasikan piagam ASEAN untuk diberlakukan secara effektif, didasarkan pada UndangUndang Nomor: 38 tahun 2008, setelah lima tahun, sejak piagam ASEAN diberlakukan.

Komunitas Asean (Asean Community) berpandangan bahwa negara anggota ASEAN harus memiliki prespektif atau berpandang keluar dan maju untuk menciptakan perdamaian hidup, stabil dan makmur, saling perduli dan terikat secara bersama dalam pembangunan yang dinamis. Pembentukan Komunitas ASEAN dilatarbelakangi oleh; (1) pengaruh negatif krisis ekonomi yang menimpa negara ASEAN pada tahun 1997. (2), didorong oleh mencuatnya beberapa isu global yang menganggu stabilitas di kawasan ASEAN seperti; terorisme, perdagangan narkotika, kehajatan lintas batas dan kelestarian lingkungan hidup.

Pilar Komunitas ASEAN disahkan pada Bali Concord II di Bali pada tanggal 7 oktober 2003 untuk bersama-sama membentuk Komunitas ASEAN paling lambat tahun 2020. Sering dengan pembentukan komunitas ASEAN dengan beberapa alasan tertentu, maka pembentukan tersebut dipercepat menjadi tahun 2015, hal ini ditegaskan dengan komitmen yang kuat oleh para pemimpin ASEAN pada KTT ASEAN ke-12 di Cebu Filipina pada tanggal 13 Januari 2007. 
Alasan dipercepat disebabkan oleh beberapa hal, diantaranya; (a) memperkuat daya saing ASEAN dalam menghadapi kompetesi global, seperti dengan India dan Cina, (b) karena adanya potensi penurunan biaya produksi di ASEAN sebesar 10-20\% sebagai dampak integrasi ekonomi, (c) untuk meningkatkan kemapuan kawasan ASEAN dengan implementasi standar dan praktik Internasional, (d) untuk menyelaraskan target pencapaian millennium 2015 (Millinium devolepment Goals 2015).

Selanjutnya pada KTT ASEAN ke-13 yang diadakan di Singapura pada Tanggal 20 November 2007, ASEAN telah menyusun cetak biru dari tiga pilar komunitas ASEAN.Cetak biru komunitas ASEAN tersebut disepakati untuk menjamin adanya tindak lanjut konkret yang harus dilakukan (action line) untuk terbentuknya komunitas ASEAN.

Tujuan Masyarakat Ekonomi Asean (MEA) adalah membentuk perekonomian ASEA yang memiliki karakteristik sebagai pasar tunggal dan basis produksi dikawasan ASEAN yang lebih dinamis dan berdaya saing, memiliki pembangunan yang setara, serta mempercepat keterpaduan ekonomi dikawasan ASEAN dan diluar kawasan ASEAN. Dalam kerjasama sosial budaya ASEAN, bidang garapannya diarahkan kepada nilai-nilai budaya, informasi, pendidikan, lingkungan hidup, ilmu pengetahuan dan teknologi, penaggulangan bencana alam, kesehatan, ketenagakerjaan, pembangunan social, pengentasan masyarakat miskin, pemberdayaan perempuan, perlindungn anak, kepemudaan dan olah raga, penaggulangan narkoba, serta peningkatan kapasitas dan kelembagaan pelayanan publik.

\section{B. Kualitas Pendidikan}

Kualitas merupakan suatu kondisi dinamis yang berhubungan dengan produk, jasa, manusia, proses dan lingkungan yang memenuhi atau melebihi harapan. Secara umum, mutu (quality) dapat didefinisikan sebagai keseluruhan karakteristik barang atau jasa yang menunjukkan kemampuannya dalam memuaskan kebutuhan konsumen, baik berupa kebutuhan yang dinyatakan maupun kebutuhan yang tersirat.

Menurut Ace Suryadi dan H.A.R Tilaar, kualitas pendidikan adalah kemampuan lembaga pendidikan dalam mendayagunakan atau memanfaatkan sumber-sumber pendidikan untuk meningkatkan kemampuan belajar secara optimal. Dari sisi kualitas pendidikan umum dan pendidikan agama diatur dalam Undang-Undang Nomor 20 tahun 2003 tentang Sistem Pendidikan Nasional secara eksplisit menyebutkan bahwa tujuan pendidikan nasional adalah untuk berkembangnya potensi peserta didik agar menjadi manusia yang beriman dan bertakwa kepada Tuhan Yang Maha Esa, berakhlak mulia, sehat, berilmu, cakap, kreatif, mandiri, dan menjadi warga negara yang demokratis serta bertanggung jawab. Peraturan Pemerintah Nomor 55 tahun 2007 tentang Pendidikan Agama dan Pendidikan Keagamaan secara eksplisit menjelaskan bahwa pendidikan agama diselenggarakan secara interaktif, inspiratif, menyenangkan, menantang, mendorong kreativitas dan kemandirian, serta menumbuhkan motivasi untuk hidup sukses. Selain itu, untuk mendorong percepatan kemampuan peserta didik dalam mengintegrasikan nilai-nilai agama dengan ilmu pengetahuan, teknologi dan seni ini, dibutuhkan serangkaian proses yang terencana dan tersistem yang 
mendorong adanya pengelolaan pendidikan agama. Secara operasional dan rinci pelaksanaan pendidikan agama di sekolah telah diatur dalam Peraturan Menteri Agama RI Nomor 16 Tahun 2010, pasal 13, dinyatakan bahwa Guru Pendidikan Agama minimal memiliki kualifikasi akademik Strata 1/Diploma IV, dari program studi pendidikan Agama dan/atau program studi agama dari Perguruan Tinggi yang terakreditasi dan memiliki sertifikat profesi guru pendidikan agama. Selanjutnya, disebutkan bahwa Guru Pendidikan Agama Islam (GPAI) harus memiliki kompetensi pedagogik, kepribadian, sosial, profesional dan kepemimpinan. Dengan demikian, GPAI harus memiliki kualifikasi akademik, sertifikat profesional dan kompetensi.

Menurut Bridge, Judd, dan Mocck (1979) bahwa hasil pendidikan merupakan fungsi produksi dari sistem pendidikan. Mutu sekolah merupakan fungsi dari dari proses pembelajaran yang efektif, kepemimpinan, peran serta guru, peran serta siswa, manajemen, organisasi, lingkungan fisik dan sumberdaya, kepuasan pelanggan sekolah, dukungan input dan fasilitas, dan budaya sekolah. Optimalisasi dari masing-masing komponen ini menentukan mutu sekolah sebagai satuan penyelenggara pendidikan. Tenner dan De Toro mendefinisikan mutu pendidikan adalah:"Quality: abasic business strategy that provides and services that completely satisfy both internal and external custumers by meeting their explicit expectation" Menurut Nursya'bani Purnama, bahwa mutu merupakan sistem organisasi yang menghasilkan lingkungan yang kondusif untuk keberlangsungan dan perbaikan mutu, dibutuhkan budaya mutu yang terdiri dari nilai-nilai, tradisi, prosedur, dan harapan tentang promosi mutu

Selanjutnya, menurut Philip B. Corsby, bahwa mutu merupakan standar yang telah ditentukan baik input, proses dan outputnya. Nasution mengutip konsep yang disampaikan oleh Calvin, mutu pendidikan yang dilaksanakan merupakan kondisi yang dinamis, saling berhubungan antara produk, tenaga kerja, tugas, serta lingkungan yang memenuhi bahkan melebihi harapan dari seorang pelanggang atau konsumen pada suatu produk, yang selalu berubah atau disesuaikan dengan perubahan dalam peningkatan keterampilan tenaga kerja, perubahan proses produksi, dan tugas, serta perubahan lingkungan organisasi untuk dapat memenuhi harapan pelangan atau konsumen. Penjaminan mutu pendidikan menurut Edwar Sallis, dapat ditinjau dari dua dimensi yang berbeda, yaitu dimensi mutu bersifat absolute dan dimensi mutu bersifat relative. Dalam konsep mutu bersifat absolute mengambarkan derajat suatu barang atau jasa yang diproduksi dan dipasok bernilai baik atau berharga dengan standar yang tinggi, ekslusif dan berkelas yang ditetapkan oleh pembuat sebagai atribut produk. Sedangkan mutu bersifat relative adalah sesuatu yang berasal dari layanan atau produk yang memenuhi spesifikasi yang ada yaitu; mengerjakan apa yang seharusnya dikerjakan dan mengerjakan sesuai dengan keinginan pelangang.

Konsep mutu pedidikan yang diinformasikan Cortada, merupakan suatu perangkat norma yang dilandasi nilai-nilai dan keyakinan yang kemudian termanifestasikan dalam perilaku, aktivitas dan symbol-simbol di sekolah untuk mencapai tingkat nilai keunggulan yang diharapkan dan dapat menciptakan akuntabilitas bagi sekolah. 
Menurut Vroeijenstijn, bahwa mutu dalam pendidikan merupakan konsep yang multi dimensi untuk memenuhi berbagai macam harapan seperti, harapan pemerintah, pemberi kerja, masyarakat luas, anak didik dan pendidik.

Menurut Soedijarto, rendahnya mutu atau kualitas pendidikan disamping disebabkan oleh pemberian peranan yang kurang propesional terhadap sekolah, kurang memadainya perencanaan, pelaksanaan dan pengelolaan system kurikulum dan penggunaan prestasi hasil belajar secara kognitif. Sebagai salah satunya indikator keberhasilan pendidikan juga disebabkan karena evaluasi tidak secara berencana didudukkan sebagai alat pendidikan yang merupakan bagian terpenting dalam system pendidikan.

Adapun hasil penelitian yang dilakukan Doyle yang dikutip oleh Kyle (1985), menyatakan, bahwa salah satu indikator dari keberhasilan atau keefektifan sekolah adalah mutu pencapaian hasil belajar siswanya, dan hasil belajar siswa tersebut akan sangat tergantung kepada keberhasilan guru dalam membantu siswa untuk mencapai hasil belajarnya. Oleh karena itu, guru mempunyai peran yang sangat menentukan bagi keberhasilan pendidikan disekolah.

Ruang lingkup penjaminan mutu sekolah, meliputi penjaminan mutu terhadap komponen-komponen sistem pendidikan, yaitu: (1) input, baik input peserta didik, guru, tenaga kependidikan maupun sumber daya yang lain, (2) proses, baik proses manajemen sekolah (termasuk pengembangan kultur sekolah) maupun proses pembelajaran dan penilaian, (3) produk atau hasil,terutama penjaminan terhadap kualitas output yang dihasilkan oleh sekolah, dan penjaminan mutu sekolah sebagai suatu sistem secara keseluruhan, dan (4) outcomes, penjaminan mutu mengenai relevansi kualitas lulusan dari suatu satuan pendidikan dengan kebutuhan.

Model Evaluasi CIPP (Content, Input, Proses, Product), merupakan model yang paling banyak dikenal oleh evaluator. Model ini dikembangkan oleh Sufflebeam dan kawan-kawan di Ohio State University. Evaluasi kualitas pendidikan agama Islam berbasis ICT dapat dilakukan dengan langkah-langkah sebagai berikut:

1) Dimensi Konteks

Evaluasi konteks dilakukan untuk mendapatkan gambaran dan rincian tentang lingkungan sekitar dan kebutuhan-kebutuhan yang tidak terpenuhi. Dalam komponen evaluasi konteks, hal-hal yang menjadi konten dalam evaluasi adalah bagaimana rumusan tujuan program, manajemen mutu, atau pengambil kebijakan dalam penjaminan mutu pendidikan.

2). Dimensi Input

Evaluasi input dilakukan utuk mengindentifikasi komponen kebutuhan dalam menjalankan program/kebijakan. Evaluasi ini dilakukan untuk menyajikan data dan ketersedian sumber-sumber yang dapat digunakan untuk mencapai tujuan program/kebijakan seperti, sarana dan prasarana, sumber daya manusia, kompetensi dan rekrutmen tenaga pendidikan dan kependidikan, kurikulum dan pembiyaan pendidikan.

3). Dimensi Proses

Evaluasi proses sebagai umpan balik yang digunakan untuk efesiensi pelaksanaan kebijakan, dan pengaruh suatu sistem pada pelaksanaan 
kebijakan-kebijakan yang dapat dilhat dari proses pembelajaran, hasil belajar, monitoring dan evaluasi pembelajaran sebagai suatu keputusan yang diambil untuk memperbaiki proses pelaksanaan pembelajaran dan penjaminan mutu.

4). Dimensi Produk

Evaluasi produk digunakan untuk mengukur ketercapaian pelaksanaan bijakan dengan menetapkan kriteria, membandingkan ukuran keberhasilan dengan standar mutu akademik dan melakukan interpretasi tentang hasil dan pengaruh dengan menggunakan data yang ada pada komponen konteks, komponen input, dan komponen proses.

Berdasarkan teori diatas dapat disintesiskan, bahwa kualitas atau mutu pendidikan dalam proses belajar dan mengajar merupakan suatu aktivitas yang dilakukan guru dan siswa yang dilakukan di dalam kelas maupun di luar kelas yang ditunjang dengan fasilitas-fasilitas pendukung pembelajaran lainnya seperti laboratrium, tanam belajar, bengkel belajar, dan lainya, yang merupakan suatu upaya proses pembalajaran untuk mencerminkan peningkatan dan kemajuan pendidikan terhadap cara berpikir, berperilaku dan berketerampilan dengan hasil belajar mengajar yang dicapai dalam bentuk perolehan nilai-nilai/angka-angka dari keseluruhan mata pelajaran yang dipelajarinya serta layanan atau produk pendidikan yang baik dan memuaskan pada pelanggan secara terus menerus dengan melakukan perbaikan-perbaikan terhadap komponen-komponen penilaian standar mutu seperti; input (masukan) proses, output (luaran) dan outcome (produk). sehingga kualitas pendidikan dapat terukur.

Dalam penelitian ini, peneliti membatasi penelitian tentang kualitas pendidikan agama Islam berbasis ICT yang ditinjau dari dimensi evaluasi kualitas pendidikan yang terdiri dari dimensi-dimensi yaitu: (1) konten, yang meliputi indikator visi, misi, dukungan, masalah pembiyaan, dan SOP sekolah dalam pendidikan, (2) input, yang meliputi input peserta didik, guru, tenaga kependidikan maupun sumber daya yang lain, (2) proses, yang meliputi proses manajemen sekolah (termasuk pengembangan kultur sekolah) maupun proses pembelajaran dan penilaian, (3) produk atau hasil, terutama penjaminan terhadap kualitas output yang dihasilkan oleh sekolah, dan mutu sekolah sebagai suatu sistem secara keseluruhan.

\section{Persepsi}

Persepsi diartikan sebagai pengamatan penyusunan dorongan-dorongan dalam kesatuan-kesatuan; hal mengetahui melalui indera; tanggapan (indera); daya memahami. Persepsi merupakan cara bagaimana seseorang mengamati dan mengetahui dan memberikan tanggapan terhadap suatu objek melalui indera yang dimilikinya. Seseorang akan melakukan tindakan sesuai dengan persepsinya untuk mempengaruhi perilaku orang.

Menurut Philip Kotler, persepsi adalah proses bagaimana seorang menyeleksi mengatur dan menginterpretasikan masukan-masukan informasi untuk menciptakan gambaran keseluruhan yang berarti. Persepsi dapat diartikan sebagai suatu proses kategorisasi dan interpretasi yang bersifat selektif. Persepsi merupakan suatu proses psikologis apabila terdapat karakteristik obyek yang 
dipresepsikan, alat indera (reseptor) dan perhatian. Obyek persepsi dapat berada didalam maupun diluar individu itu sendiri.

Menurut Heider (1958), persepsi merupakan suatu proses psikologis yaitu adanya obyek yang dipersepsikan, alat (indera) dan perhatian. Persepsi seseorang biasa muncul dari dalam diri maupun diluar diri individu. Jika obyek persepsi berada didalam individu yang mempersepsi, berarti individu tersebut mempersepsikan dirinya sendiri, untuk memahami dan mengetahui, serta mengevaluasi keadaan yang terjadi di dalam dirinya. Sebaliknya jika persepsi itu muncul berada diluar dirinya, maka obyek persepsi dapat berupa benda-benda, situasi atau manusia itu sendiri.

Kreach (1962) menginformasikan bahwa persepsi merupakan integrasi dari individu dan rangsangan yang diterimanya. Menurut Siegel dan Marconi (1989), persepsi merupakan suatu proses dari seorang dalam menyeleksi, mengorganisir dan menginterpretasikan rangsangan kedalam sesuatu yang berarti dan koheren dengan dunia.

Selanjutnya Bower mengemukakan, bahwa Persepsi ialah interpretasi tentang apa yang diinderakan atau dirasakan individu. Sementara Gibson menginformasikan bahwa persepsi merupakan suatu proses pengenalan maupun proses pemberian arti terhadap lingkungan oleh individu.

Menurut Huffman (1987), persepsi merupakan proses penyeleksian, pengorganisasian dan penyimpanan data informasi ke dalam sebuah gambaran yang dapat dipahami.Dalam mempersepsikan suatu obyek, terdapat beberapa faktor yang dapat mempengaruhi persepasi individu untuk melihat suatu objek. Faktor-faktor yang mempengaruhi diantaranya: (a) tingkat pengetahuan seseorang dalam memahami suatu obyek yang dipersepsikan, (b) karakteristik kepribadian seseorang dalam mempersepsikan suatu obyek, yang terlihat dari sikap, kepentingan, motivasi diri, pengalaman dan pengharapan yang dimikilinya.Dalam proses pembelajaran persepsi yang muncul dari seorang murid dan seorang pendidik secara umum dapat meliputi tiga dimensi yaitu; afektif, kognitif, dan psikomotorik.

Menurut Williams (1970) dimensi proses belajar yang mencakup tiga ranah dirancang untuk membantu guru dan siswa dalam menentukan tugas-tugasnya didalam kelas. Adapun dimensi-dimensi dalam pendidikan diantaranya; 1), dimensi kurikulum (materi/ konten), 2), dimensi perilaku siswa (kegiatan belajar) dan 3), dimensi perilaku guru (strategi/ cara mengajar).

Dimensi perilaku kognitif (intelektual) dan affektif (perasaan) yaitu; a. Perilaku Intelektual (kognitif) yaitu;

1) berpikir lancar menghasilkan banyak gagasan/jawaban yang releven, arus pemikiran lancar.

2) berpikir luwes (fleksibel) yaitu, menghasilkan gagasan-gagasan yang beragam, mampu mengubah cara atau pendekatan, arah pemikiran yang berbeda-beda.

3) berpikir orisinal yang memberikan jawaban yang tidak lazim, yang lain dari yang lain, yang jarang diberikan kebanyakan orang.

4) berpikir terperinci (elaborasi) yaitu, mengembangkan, menambah, memperkaya suatu gagasan memperinci detil-detil memperluas suatu gagasan.

b. Dari aspek afektif (perasaan) terdiri atas; 
1) mengambil risiko tidak takut gagal atau dikritik, berani membuat dugaan dan mempertahankan pendapat.

2) merasakan tantangan mencari banyak kemungkinan, dan melihat kekurangankekurangan yang ada.

3) rasa ingin tahu yaitu, mempertanyakan sesuatu.

4) imajinasi/firasat yaitu, mampu membayangkan, membuat gambaran mental, merasakan firasat, mengimpikan hal-hal yang belum pernah terjadi.

Berdasarkan teori-teori diatas dapat disintesiskan bahwa persepsi dalam pembelajaran merupakan proses penyeleksian, pengorganisasian dan penyimpanan data informasi ke dalam sebuah gambaran yang dapat dipahami serta dipengaruhi oleh tingkat pengetahuan seseorang dalam memahami suatu obyek yang dipersepsikan, dan karakteristik kepribadian seseorang dalam mempersepsikan suatu obyek, yang terlihat dari sikap, kepentingan, motivasi diri, pengalaman dan pengharapan yang dimikilinya. Persepsi dalam proses pembelajaran dirancang untuk membantu guru dan siswa dalam menentukan tugas-tugasnya didalam kelas. Persepsi dapat diukur berdasarkan sikap (affektif) perasaan yang terdiri dari; (1) perasaan mau mengambil risiko tidak takut gagal atau dikritik, berani membuat dugaan dan mempertahankan pendapat.(2) perasaan mau merasakan tantangan mencari banyak kemungkinan, dan melihat kekurangan-kekurangan yang ada. (3) perasaan rasa ingin tahu yaitu, mempertanyakan sesuatu.(4) memiliki imajinasi/firasat yaitu, mampu membayangkan, membuat gambaran mental, merasakan firasat, mengimpikan halhal yang belum pernah terjadi.

Sementara persepsi berdasarkan pengetahuan (kognitif) dapat diukur berdasarkan: (1) berpikir lancar menghasilkan banyak gagasan/jawaban yang releven, arus pemikiran lancar. (2) berpikir luwes (fleksibel) yaitu, menghasilkan gagasan-gagasan yang beragam, mampu mengubah cara atau pendekatan, arah pemikiran yang berbeda-beda. (3) berpikir orisinal yang memberikan jawaban yang tidak lazim, yang lain dari pada yang lain, yang jarang diberikan kebanyakan orang. (4) berpikir terperinci (elaborasi) yaitu, mengembangkan, menambah, memperkaya suatu gagasan memperinci detil-detil memperluas suatu gagasan.

Dalam penelitian ini, peneliti membatasi pembahasan mengenai persepsi guru PAI dalam dua faktor yang mempengaruhi persepsi yaitu; (a) faktor berupa persepsi sikap, perasaan dan (b) pengetahuan dalam pengorganisiran data(kualitas pendidikan agama Islam berbasis ICT) kedalam gambaran yang dipahami.

\section{Pendidikan Agama Islam}

Pendidikan dalam istilah bahasa Arab, didefinisikan dengan berbagai macam arti kata dan bahasa, diantara yang populer, yang sering disingkronkan oleh para ahli tentang istilah pendidikan yang ditinjau dari segi bahasa terdapat dalam rangkaian kata yaitu; (1) at-tarbiyah, (2) at-tadris; (3) at-ta'lim (4) attadib; (5) at-tahzib dan (6) al-insya; Dari keenam istilah ini, penggunaan rangkaian kata" at-tarbiyah" paling banyak digunakan dalam memaknai pendidikan di Indonesia dan lebih luas lagi digunakan sebagai pengertian pendidikan pada negara-negara yang menggunakan bahasa Arab sebagai bahasa ibu dalam negera tersebut. 
Abu Tauhid, dalam Mangun Budiyanto, mengungkapkan bahwa, istilah attarbiyah dalam pendidikan lebih luas digunakan sekarang di negara-negara yang menggunakan bahasa Arab dari pada kata at-ta'lim dan - at-tadris. Karena kata atta'lim dan at-tadris lebih banyak ditujukan untuk istilah pengajaran yang hanya terbatas pada kegiatan menyampaikan atau memasukkan ilmu pengetahuan ke otak seseorang, atau dengan kata lain bahwa at-tadris dan at-talim hanya merupakan bagian dari pendidikan. Selanjutnya kata ta-dib; lebih banyak hanya ditujukan untuk istilah pendidikan akhlak semata, dan kata tahzib; lebih banyak ditujukan pada istilah pendidikan keterampilan. Kata insya' dalam pendidikan lebih banyak ditujukan untuk istilah pertumbuhan fisik seseorang. Sedangkan kata at-tarbiyyah mempunyai pengertian yang lebih luas dari istilah-istilah tersebut.

Sementara itu lahirnya terma-terma (term) dalam konteks pendidikan yang identik dengan teori-teori barat. Pokok pemikiran pendidikan tersebut lebih memfokuskan pada pembahasan mengenai jabaran tugas pendidik secara umum, yaitu mendidik untuk mengupayakan perkembangan seluruh potensi anak didik, baik potensi psikomotorik, kognitif maupun potensi afektif. Paulo Freire (1973) mengungkapkan bahwa pendidikan merupakan "famously called these bankingmaking deposits of knowledge. Such 'Schooling' quickly descends into treating learners like objects, thinks tobe acted upon rather than people tobe related to".

Syaid Syabiq dalam kitabnya berjudul" Islamuna" yang dimaksud dengan pendidikan adalah menyiapkan anak baik dari segi jasmani, akal, dan rohaninya sehingga dia menjadi anggota masyarakat yang bermanfaat, baik untuk dirinya maupun bagi umatnya.

Selanjutnya Athiyah Al-Abrasyi menyatakan bahwa yang dimaksud dengan pendidikan adalah menyiapkan individu agar dapat hidup dengan kehidupan yang sempurna.Definisi yang disampaikan oleh M. Athiyah Al-Abrasyi, dapat dipahami bahwa pendidikan adalah memiliki tujuan untuk menyiapkan individu agar dapat hidup dengan kehidupan yang sempurna dan mengalami pertumbuhan secara terus menerus semenjak dari lahir sampai meninggal dunia. Tinjauan konsep pendidikan dalam konsep diatas, dapat diformulasikan sebagai berikut:

a. Pendidikan adalah suatu proses pembelajaran untuk mempersiapkan dan menumbuh kembangkan kepribadian, karakter siswa dari semenjak lahir sampai meninggal dunia.

b. Pendidikan membentuk jasmani, akal dan rohani tanpa mengesamping satu aspek dan melebihkan aspek yang lainnya.

c. Pendidikan dipersiapkan untuk menumbuhkan keyakinan, rasa tanggung jawab yang tinggi, berdaya guna serta dapat memperoleh suatu kehidupan yang sempurna.

d. Pendidikan merupakan integrasi ilmu yang saling berkaitan satu dengan yang lainnya yang tidak dapat dipisahkan baik secara kognisi, afeksi dan psikomotorik.

Dalam proses pendidikan agama Islam, agama mengatur berbagai dimensi hubungan manusia dengan Maha pencipta, dimensi hubungan manusia dengan manusia, dan dimensi hubungan manusia dengan alam atau mahluk lainya. Dari sudut pandang secara bahasa (etimologis), agama berarti peraturan-peraturan tradisional, ajaran-ajaran, kumpulan-kumpulan hukum yang secara diturun- 
temurun dan ditentukan oleh adat istiadat. Beberapa pendapat tentang definisi agama yang dirumuskan oleh para ahli yang dikutip oleh Yatimin Abdullah dalam bukunya "Studi Islam Kontemporer" dapat dikemukakan sebagai berikut: 1), Durkhein menegaskan, bahwa makna agama serupa dengan apa yang ada dibelakang akal, yaitu segala sesuatu yang lebih tinggi dari pada pencapaian pendapat akal kita. Jadi agama adalah alam ghaib yang tidak dapat diketahui dan tidak dapat dipikirkan oleh akal dan pikiran manusia sendiri.Tegasnya agama adalah suatu bagian dari pengetahuan yang tidak dapat dicapai oleh ilmu pengetahuan biasa dan tidak dapat di peroleh dengan pikiran saja. 2), Brunetiere mendifinisikan agama sebagai sesuatu yang lain dari biasa. Pendapat ini tidak disetujui oleh Durkhein, sebab Brunetiere mendefinisikan agama lebih jauh dari makna agama yang sebenarnya.Yatimin Abdullah mengutip pendapat Sahiliun A. Nasir dalam buku Pokok-pokok pendidikan agama Islam, bahwa alasan untuk mengambarkan sesuatu hal yang luar biasa supaya dapat dipahami makna agama, dapat diartikulasikan sebagai sekumpulan kewajiban manusia kepada Allah, masyarakat dan dirinya sendiri. Agama adalah sejumlah pesan dan kepercayaan yang harus mengarahkan kepada tingkah laku terhadap Allah, manusia dan terhadap alam semesta. 3) Asy-Syahrastani berpendapat, bahwa agama adalah ketaatan dan kepatuhan yang terkadang bisa diartikan sebagai pembalasan dan perhitungan (amal perbuatan di akhirat). 4), Ath-Thanwy menyebutkan bahwa agama adalah intisari Tuhan yang mengarahkan orang-orang yang berakal dengan kemauan mereka sendiri untuk memperoleh kesejahteraan hidup didunia dan di akhirat.

Berdasarkan definisi diatas, secara umum dapat dimaknai, bahwa agama adalah suatu pengetahuan yang melebihi kekuatan akal dan pikiran manusia yang di dalamnya mengadung sejumlah pesan dan kepercayaan yang mengarahkan tingkah laku kita untuk patuh dan taat serta melaksanakan kewajiban kepada Allah, manusia dan kewajiban kita kepada alam semesta, sehingga memperoleh kesejahteraan hidup didunia dan diakhirat.

M. Natsir berpendapat, bahwa agama Islam adalah agama kepercayaan dan cara hidup yang mengandung faktor-faktor; (a) percaya adanya Tuhan sebagai sumber dari segala hokum dan nilai-nilai hidup (b) percaya adanya wahyu, (c) percaya adanya hubungan antara Allah dengan manusia, (d) percaya bahwa matinya seseorang, hidup rohnya tidak berakhir, (e) percaya bahwa keridhaan Allah sebagai tujuan hidup.

Mukti Ali, mengatakan bahwa agama Islam adalah agama kepercayaan adanya Allah dan hukum yang diwahyukan kepada utusan-utusan-Nya para Nabi untuk kebahagian hidup manusia.

Sementara itu, Muhaimin mengistilahkan pendidikan Islam dalam prespektif bagian-bagian dari pendidikan Islam itu sendiri seperti; (a) pendidikan menurut Islam, (b) pendidikan ke-Islaman (c) pendidikan dalam Islam. Pendidikan menurut Islam merupakan pendidikan yang dipahami dam dikembangkan berdasarkan susunan ajaran-ajaran Islam yang fundamental yang terkandung dalam al-Quran dan al-Sunnah. Adapun pendidikan ke-Islaman, dapat dipahami sebagai upaya untuk mendidik ajaran agama dan nilai-nilai keislaman sebagai way of life (pandangan dan sikap hidup) seseorang. Pendidikan dalam Islam merupakan suatu 
proses dan praktik terhadap pendidikan seperti proses pembudayaan, pewarisan ajaran agama, dan peradaban umat Islam secara turun termurun kepada generasi ke generasi sepanjang sejarah. Zakiyah Darajat memberikan definisi yang berbeda berdasarkan tinjauanya dari segi pembinaan dan pola pengasuhan, menjelaskan bahwa pendidikan dalam Islam adalah suatu usaha bimbingan atau asuhan terhadap pesertadidik, untuk memahami ajaran dalam Islam secara keseluruhan, menghayati makna dan tujuan yang pada akhirnya dapat mengamalkan ajaranajaran Islam sebagai pandangan hidupnya.

Berdasarkan teori-teori diatas, maka dapat disintesiskan bahwa, pendidikan agama Islam yang dimaksud dalam definisi, pendapat dan konsep yang disampaikan para ahli dapat diformulasikan sebagai suatu model pendidikan dalam proses pembelajaran pendidikan agama Islam dengan bertujuan untuk membentuk perilaku, (affektif) yang baik dan benar, membentuk pengetahuan (kognitif) serta mengandung unsur pembinaan, pembiasaan secara terampil (psikomotorik) untuk mencapai keridhoaan Allah swt, dengan menyadari dan iklash menjalankan kewajibannya kepada Allah Swt, mengetahui hak-hak manusia dan alam semesta, untuk mendapatkan kesejahteraan, kebahagiaan hidup didunia dan akhirat. Hakekat pendidikan Islam merupakan suatu proses tanpa akhir yang bertumpu pada dua aspek, yaitu pendidikan untuk menanamkan tauhid (keyakinan beragama) dan pendidikan untuk membentuk dan mengembangkan karakter (afektif) pengetahuan (kognisi) dan keterampilan pesertadidik.

\section{E. Pembelajaran Berbasis ICT}

Sejarah pembelajaran berbasis komputer dimulai dari munculnya ide-ide untuk menciptakan perangkat teknologi terapan yang memungkinkan seseorang melakukan proses belajar secara individual dengan menerapkan Prinsip-prinsip didaktik-metodik. Mesin mengajar pada mulanya diciptakan oleh Sydney.L Pressey (1960) untuk melakukan tes terhadap capaian hasil belajar. Mesin mengajar yang diciptakan Pressey dalam pandanganya dapat digunakan pula dalam mengajar, dengan sedikit merubah tujuan, dari tujuan menguji menjadi tujuan mengajar. Penggunaan alat bantu komputer dan pemanfaatannya dalam bidang pendidikan, khususnya dalam pembelajaran.

Menurut Rusman sebenarnya mata rantai dari sejarah teknologi pembelajaran. Sejarah teknologi pembelajaran merupakan suatu kreasi berbagai ahli dalam bidang terkait, yang pada dasarnya ingin berupaya dalam mewujudkan ide-ide praktis dalam menetapkan prinsip-prinsip didaktik, yaitu pembelajaran yang menekankan perbedaan individual baik dalam kemampuan maupun dalam kecepatan.Teknologi Informasi dan komunikasi telah berkembang seiring dengan globalisasi, kemajuan teknologi informasi dan komunikasi menjadikan interaksi dan penyampaian informasi berlangsung dengan cepat. Pengaruh globalisasi dalam penggunaan teknologi ini dapat bernilai positif dan negatif pada suatu Negara. Pertukaran informasi, ilmu pengetahuan dan tekonologi terbaru yang sangat cepat dapat mempengaruhi pendidikan orang-orang yang mampu untuk berkompetensi dan yang tidak mampu bersaing dalam mengakses teknologi ICT atau sering diistilahkan sebagai (digital-devide). 
Kebijakan Pemerintah Indonesia atas penggunaan ICT didasarkan pada Keppres.No.50/2000 tentang Pengadaan Tim Koordinasi Telematika Indonesia.Telematika adalah kepanjangan dari Teknologi Komunikasi, Media dan Informatika, yang mengacu pada pemanfaatan ICT dalam berbagai sektor dan aspek kehidupan.

Kurikulum berbasis ICT dalam sektor pendidikan dikenal dengan program pendidikan e-education, yaitu pemanfaatan program telematika pendidikan atau pemanfaatan ICT dalam pendidikan. Pengembangan program penddikan $e$ education ini, dibawah naungan Menteri Pendidikan dan Kebudayaan Nasional dengan tujuan pelaksanaan adalah:

a. Mengembangkan ICT network untuk umum dan universitas seperti riset dan pendidikan network di Indonesia.

b. Mempersiapkan suatu rancangan pengembangan sumber daya manusia dalam mengaplikasikan ICT.

c. Mengembangkan dan menerapkan kurikulum berbasis ICT.

d. Menggunakan ICT sebagai suatu bagian dari kurikulum pembelajaran disekolah, universitas dan pusat-pusat latihan.

e. Mengadakan program yang berhubungan dengan pendidikan dengan mengikutsertakan sekolah-sekolah dalam pembelajaran yang seluas-luasnya.

f. Memfasilitasi penggunaan internet dengan efesien dalam proses pembelajaran.

Menurut Yuhetty, dimasa datang kurikulum sekolah dan kurikulum pada pendidikan lebih tinggi secara berangsur-angsur menyesuaikan diri pada aspek ICT mulai dari pendidikan tinggi dan sekolah menegah. Hal ini terkait dengan peningkatan mutu pendidikan dan kompetensi dengan sasaran pendidikan dalam pemanfaatan media pembelajaran berbasis ICT. Pemanfaatan dan penggunaan ICT dalam penerapanya terdapat dua macam penerapan dalam pembelajaran yaitu; 1) penerapan pembelajaran dengan bantuan komputer sebagai (Computer Assisted Instruction) CIA. 2), pembelajaran berbasis ICT (Computer based Instruction) CBI.

Secara sederhana pemanfaatan Teknologi Informasi dan Komunikasi (TIK) ditinjau dari aspek teknologi informasi merupakan suatu teknologi yang digunakan untuk mengolah data yang termasuk didalamnya adalah memproses, mendapatkan, menyusun, menyimpan, memanipulasi, dan mengirim pesan dalam berbagai cara untuk menghasilkan informasi yang berkualitas, akurat relevan dan tepat waktu. Sedangkan aspek teknologi dalam komunikasi merupakan segala sesuatu yang berkaitan dengan penggunaan alat untuk mentransfer data, file, dari perangkat satu keperangkat yang lain. Teknologi Informasi dan Komunikasi dalam pembelajaran merupakan suatu integrasi perangkat dan produk dalam kurikulum pembelajaran berbasis ICT, baik berupa perangkat keras dan perangkat lunak. Pembelajaran berbasis ICT pada umumnya menyampaikan informasi tentang suatu proses pembelajaran berupa materi ajar, sehingga pembelajaran yang diharapkan menjadi effektif dan menghasilkan suatu produk/hasil pembelajaran yang baik dan effektif pula.

Dalam proses pembelajaran berbasis ICT elemen-elemen proses pembelajaran saling terkait yang tertuang dalam aspek kurikulum, sebagai dasar dalam perumusan tujuan pembelajaran, pemenuhan bahan pembelajaran atau 
bahan ajar, starategi, model dan evaluasi dalam pembelajaran. Dari seluruh elemen yang saling terkait memposisikan ICT sebagai alat bantu (support) pencapain target kurikulum, sebagai tambahan (supplement), pelengkap (complement) pengayaan (encrichment) dan pengganti (subtitutions) sebagai suatu sistem pembelajaran modern sebagaimana yang terdapat dalam kurikulum.

Adapun pembelajaran berbasis komputer (CBI) sebagai perangkat lunak yang dimanfaatkan sebagai (CAI), juga dimanfaatkan sebagai sebagai sistem pembelajaran Individul (individual learning) yang berfungsi untuk memfasilitasi belajar kepada individu yang memanfaatkanya. Oleh karena itu, pengembangan perangkat lunak CBI harus mempertimbangkan prinsip-prinsip pembelajaran, prinsip-prinsip perencanaan pembelajaran dan prinsip-prinsip pembelajaran individual yang langsung berinteraksi dengan media interaktif berbasis komputer bagi siswa, sementara guru bertindak sebagai desainer dan programmer pembelajaran.

Berdasarkan teori diatas dapat disentesiskan, bahwa pendidikan berbasis ICT merupakan sutau model pembelajaran yang saling terkait yang tertuang dalam aspek kurikulum, sebagai dasar dalam perumusan tujuan pembelajaran, pemenuhan bahan pembelajaran atau bahan ajar, starategi, model dan evaluasi dalam pembelajaran.

\section{Hipotesis dan Metode}

Berdasarkan teori dan kerangka berpikir maka hipotesisnya dapat diformulasikan sebagai berikut: (1) Pendidikan agama Islam berbasis ICT di Kota Gorontalo paling tinggi diduga mencapai $80 \%$ dari kriteria yang diharapkan. (2) persepsi sikap dan pengetahuan guru PAI terhadap pendidikan agama Islam berbasis ICT diera Masyarakat Ekonomi Asean (MEA) di Kota Gorontalo paling baik mencapai $70 \%$ dari kriteria yang diharapkan, (3) terdapat hubungan yang positif dan signifikansi antara kualitas pendidikan dan persepsi sikap (Affektif) dan pengethauan (Kognitif) guru PAI terhadap pendidikan agama Islam berbasis ICT dieara Masyarakat Ekonomi Asean (MEA) di sekolah di Kota Gorontalo (4) Persepsi guru PAI terhadap pendidikan agama Islam berbasis ICT dalm peningkatan kualitas pendidikan merupakan varian/ faktor yang menentukan sikap dan pengetahuan guru dalam meningkatkan kualitas pendidikan yang ada disekolah diera MEA.

Desain model metode dalam penelitian ini menggunakan metode kombinasi (Mixed Methods). Dalam penelitian ini model metode kombinasi yang digunakan yaitu model Sequential Explonatory Design. Creswell(2009) dalam Sugiyono, menyatakan bahwa:" Explanatory Strategy in mixed method research is characterized by collection and analysis of quantitative data in a first phase followed by the collection and analysis of qualitative data in a second phase that build on the result of initial quantitative result. Metode penelitian kombinasi model sequential explanatory, dicirikan dengan mengumpulkan data dan analisis data kuantitatif pada tahap pertama, dan diikuti dengan pengumpulan data analisis kualitatif pada tahap kedua, guna memperkuat hasil penelitian kuantitatif yang dilakukan pada tahap pertama. Populasi dalam penelitian ini adalah para guru pendidikan agama Islam (PAI) yang ada di Kota Gorontalo yang merupakan 
generalisasi dari keseluruhan guru pendidikan agama Islam yang berjumlah sekitar 72 orang. sampel yang diambil untuk dijadikan obyek dalam penelitian, dilakukan secara Proportionate Stratified Random Sampling atau pengambilan anggota sampel dari populasi yang mempunyai anggota unsur yang tidak homogen dan berstrata secara proposional.Teknik penarikan sampling dilakukan dengan taraf kepercayaan sampling terhadap gunakan populasi yakni $95 \%$, dengan tingkat kesalahan (presesi) sebesar 5\%.

Teknik analisis data yang digunakan adalah mengkombinasikan data kuantitatif dan kualitatif secara berurutan dengan pendekatan analisis deskriptif dan analisis inferensial. Analisis deskriptif digunakan untuk mengambarkan data dari masing-masing variabel penelitian dengan ditunjukkan melalui tabulasi data pada dimensi dan pada setiap indikator-indikator dalam variabel penelitian. Analisis inferensial digunakan untuk menguji hipotesis dengan teknik analisis uji $\mathrm{t}$ dan regresi sederhana pada data kuntitatif, kemudian membandingkan data kuantitatif dengan data kulitatif memlalui hasil wawancara yang telah dianalisis dan selanjutnya ditarik kesimpulan hasil penbndingakan data kuantitatif da kualitatif.

\section{Hasil Penelitian}

a). ). Variabel Kualitas Pendidikan Agama Islam Berbasis ICT.

Hasil pengolahan data, dapat disimpulkan bahwa tingkat persetujuan pada variabel kualitas pendidikan agama Islam berbasis ICT memiliki interpretasi nilai $=85,6 \%$ terletak pada posisi yang sangat baik, sedang tingkat persetujuan (nilai kontinum) untuk jawaban ragu-ragu $=70 \%$, tidak setuju $=46,6 \%$, dan sangat tidak setuju memiliki nilai $=23,3 \%$ yang terletak pada daerah yang lemah, dari nilai $100 \%$ yang diharapkan. Adapun tingkat porsentase pada masingmasing kategori dapat disajikan dalam bentuk diagram sebagai berikut :

Diagram Line 4.3: Kategori Persetujuan Data Variabel Kualitas PAI Berbasis ICT setelah uji coba

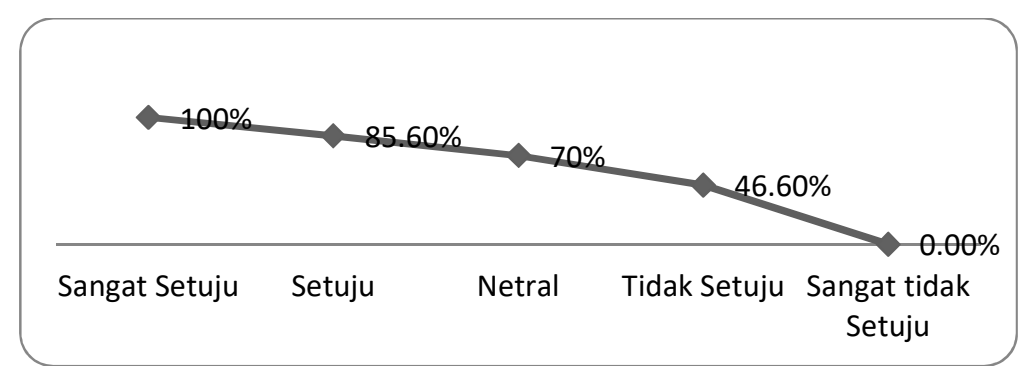

b). Variabel persepsi guru PAI terhadap pendidikan agama Islam berbasis ICT

Dari hasil pengolahan data, dapat disimpulkan bahwa persepsi guru PAI terhadap pendidikan agama Islam berbasis ICT pada tingkat persetujuan memiliki interpretasi nilai $80 \%$ yang terletak pada kategori baik, sedang tingkat persetujuan (nilai kontinum) untuk jawaban ragu-ragu 74\%, tidak setuju 49,3\%, 
dan sangat tidak setuju memiliki nilai $24,6 \%$ yang terletak pada daerah yang lemah, dari skor nilai $100 \%$ yang diharapkan. Tingkat porsentase pada masingmasing kategori persetujuan dapat disajikan dalam bentuk diagram sebagai berikut:

Diagram Line 4.4 : Kategori Persetujuan Data Variabel Persepsi Guru PAI Terhadap Pendidikan Agama Islam Berbasis ICT

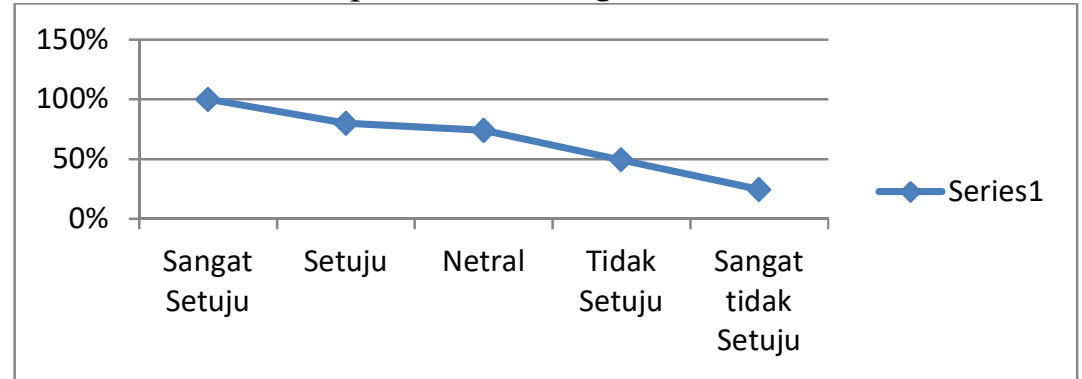

\section{Variabel Kualitas Pendidikan Agama Islam Berbasis ICT.}

Berdasarkan data yang terkumpul dari 61 responden yang memberikan tanggapan terhadap kualitas pendidikan agama Islam berbasis ICT di sekolah di Kota Gorontalo, setelah diolah dan dianalisis dengan cara mentabulasikan jumlah skor pengumpulan data dengan jumlah skor ideal, maka diperoleh harga porsentase yang diberikan sebesar $85,6 \%$. Hal ini menunjukkan bahwa kualitas pendidikan agama Islam berbasis ICT yang terjadi di sekolah di Kota Gorontalo berdasarkan responden yang memberikan jawaban berada pada posisi yang sangat bai. Asumsi ini dapat dijelaskan melalui hasil pengumpulan data pada variabel kualitas pendidikan agama Islam berbasis ICT yang mencapai jumlah skor total $=11.762$, adapun asumsi skor dari ketentuan jumlah skor ideal yang diharapkan apabila responden menjawab dengan nilai tertinggi 5 adalah sebesar 13.725, dengan harga posentase yang diharapkan mencapai $100 \%$. Dengan demikian dapat disimpulkan, bahwa kualitas pendidikan agama Islam berbasis ICT berada pada posisi yang sangat baik.

\subsection{Deskripsi Data Pada Dimensi Dan Indikator-Indikator Kualitas Pendidikan Agama Islam Berbasis ICT.}

Untuk mendapatkan gambaran atau deskipsi tentang kualitas pendidikan agama Islam berbasis ICT secara terperinci, maka dimensi-dimensi dalam variabel penelitian kualitas pendidikan agama Islam berbasis ICT, diukur dengan melihat hasil olahan skor pada setiap indikator dan pertanyaan yang disajikan dalam bentuk porsentase capaian (\%) sebagai berikut:

\section{1) Dimensi Konteks}

Tabel 4.3: Dimensi Konteks Dan Indikator Variabel Mutu PAI Berbasis ICT

\begin{tabular}{|c|l|c|}
\hline No & \multicolumn{1}{|c|}{ Indikator } & Porsentase Skor \\
\hline 1 & Penguatan informasi & $88,9 \%$ \\
\hline 2 & Pelaksanaan Visi dan misi & $87.2 \%$ \\
\hline 3 & $\begin{array}{l}\text { Dukungan orang tua dan } \\
\text { pemerintah }\end{array}$ & $86.5 \%$ \\
\hline
\end{tabular}




\begin{tabular}{|c|l|c|}
\hline 4 & $\begin{array}{l}\text { Rencana program strategis dan } \\
\text { unggulan }\end{array}$ & $84,7 \%$ \\
\hline 5 & $\begin{array}{l}\text { Menejemen pengawasan, } \\
\text { evaluasi dan pembiayaan }\end{array}$ & $83,6 \%$ \\
\hline 6 & Standar SOP dan pembiayaan & $85,2 \%$ \\
\hline \multicolumn{2}{|c|}{ Posentase total dimensi konteks } & $\mathbf{8 5 , 5 \%}$ \\
\hline
\end{tabular}

Dengan demikian secara keseluruhan analisis untuk dimensi konten pada kualitas pendidikan agama Islam berbasis ICT yang ada di sekolah Kota Gorontalo menunjukkan hasil capaian yang baik.

2) Dimensi Input

Tabel 4.4: Analisis Dimensi Input Dan Indikator Kualitas PAI Berbasis ICT

\begin{tabular}{|l|l|c|}
\hline No & \multicolumn{1}{|c|}{ Indikator } & Porsentase skor \\
\hline 1 & Standar kompentensi pendidik & $86,2 \%$ \\
\hline 2 & Standar sarana dan prasarana & $84.1 \%$ \\
\hline \multicolumn{2}{|l|}{ Posentase total dimensi input } & $\mathbf{8 5 , \%}$ \\
\hline
\end{tabular}

Berdasarkan tabel 4.3 dapat disimpulkan bahwa deskripsi tentang dimensi input pada variabel kualitas pendidikan agama Islam berbasis ICT termasuk pada kategori sangat baik. Dalam penelitian ini, menunjukkan bahwa input kualitas pendidikan agama Islam berbasis ICT di sekolah di Kota Gorontalo berada pada posisi yang sangat baik, dengan menjalankan program, kebijakan dan menentukan bagaimana ketersediaan sumber-sumber yang dapat digunakan untuk mencapai tujuan kebijakan secara baik.

\section{2) DimensProses}

Tabel 4.5: Analisis Dimensi Proses Dan Indikator Pada Kualitas PAI Berbasis ICT

\begin{tabular}{|l|l|c|}
\hline No & \multicolumn{1}{|c|}{ Indikator } & Porsentase \\
\hline 1 & $\begin{array}{l}\text { Unjuk kerja dalam proses } \\
\text { pembelajaran }\end{array}$ & $85,2 \%$ \\
\hline 2 & Kepribadian beragama & $91,2 \%$ \\
\hline \multicolumn{2}{|c|}{ Posentase total dimensi proses } & $\mathbf{8 8 , 4 \%}$ \\
\hline
\end{tabular}

Berdasarkan tabel 4.5 tersebut menunjukkan bahwa dimensi proses yang dilakukan untuk mengukur kualitas pendidikan agama Islam bebasis ICT di sekolah di Kota Gorontalo menunjukkan posisi yang sangat baik dengan harga porsentase yang dicapai sebesar $88,4 \%$. Hal ini menunjukkan bahwa proses pendidikan agama Islam berbasis ICT di sekolah di Kota Gorontalo, dari segi kebutuhan yang berkaitan dengan efisiensi pelaksanaan program pembelajaran dan kebijakan termasuk sistem pendidikan dan pelaksanaanya berjalan dengan sangat baik.

\section{4). Produk}


Tabel 4.6: Analisis Dimensi Produk Dan Indikator Kualitas PAI Berbasis ICT

\begin{tabular}{|l|l|c|}
\hline No & \multicolumn{1}{|c|}{ Indikator } & Porsentase \\
\hline 1 & $\begin{array}{l}\text { Hasil belajar dan mengajar yang } \\
\text { berkualitas }\end{array}$ & $83 \%$ \\
\hline 2 & Pengembangan dan penelitian & $75,6 \%$ \\
\hline \multicolumn{2}{|l|}{ Posentase total dimensi proses } & $\mathbf{7 9 \%}$ \\
\hline
\end{tabular}

Berdasarkan tabel 4.6 tersebut menunjukkan bahwa dimensi produk yang dilakukan untuk mengukur kualitas pendidikan agama Islam bebasis ICT di sekolah di Kota Gorontalo menunjukkan posisi yang baik dengan harga porsentase yang dicapai sebesar $=79 \%$. Dengan demikian pelaksanaan untuk menghasilkan produk dalam kegiatan pembelajaran dan standar mutu dalam pendidikan terlaksana dengan kategori yang baik.

Secara keseluruhan analisis variabel kualitas pendidikan agama Islam berbasis ICT yang terdiri dari dimensi : 1) konten, 2) input, 3) proses, dan 4) produk, dapat disimpulkan, bahwa hasil capaian berada pada posisi yang sangat baik dengan rata-rata $=85,6 \%$, dari keseluruhan dimensi yang digunakan untuk mengukur kualitas pendidikan agama Islam berbasis ICT di sekolah tingkat SMP, SMA dan SMK Kota Gorontalo.

Data analisis seluruh dimensi pada variabel kualitas pendidikan agama Islam berbasis ICT di sekolah di Kota Gorontalo dapat disajikan melalui diagram berikut:

Diagram 4.5: Analisis Seluruh Dimensi Variabel Kualitas PAI Berbasis ICT

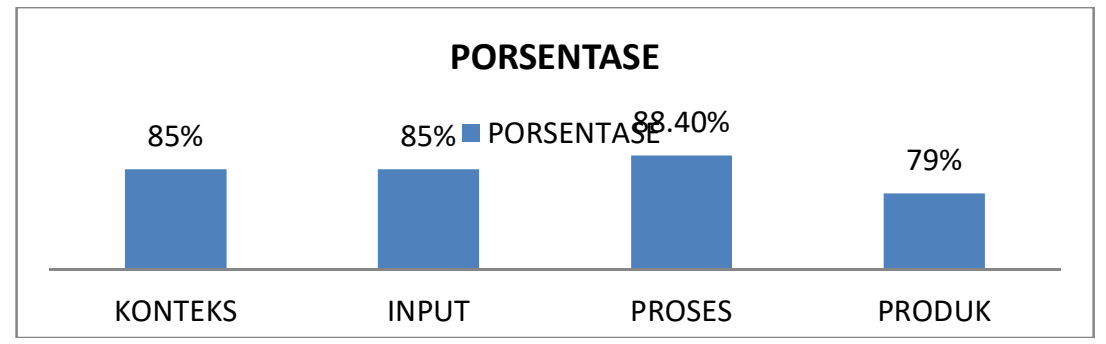

\subsection{Analisis Data Reponden Pada Tingkat Sekolah Menengah (SMP, SMA dan SMK) Variabel Mutu Pendidikan Agama Islam Berbasis ICT Kota Gorontalo,}

Analisis pengelohan data selanjutnya dilakukan untuk mengetahui perbedaan kualitas pendidikan agama Islam berbasis ICT pada tingkatan sekolah menengah (SMP,SMA, dan SMK).

Diagram Pie 4.6: Analisis Data pada Tingkat Sekolah Menengah Kota Gorontalo Variabel Kualitas PAI Berbasis ICT 


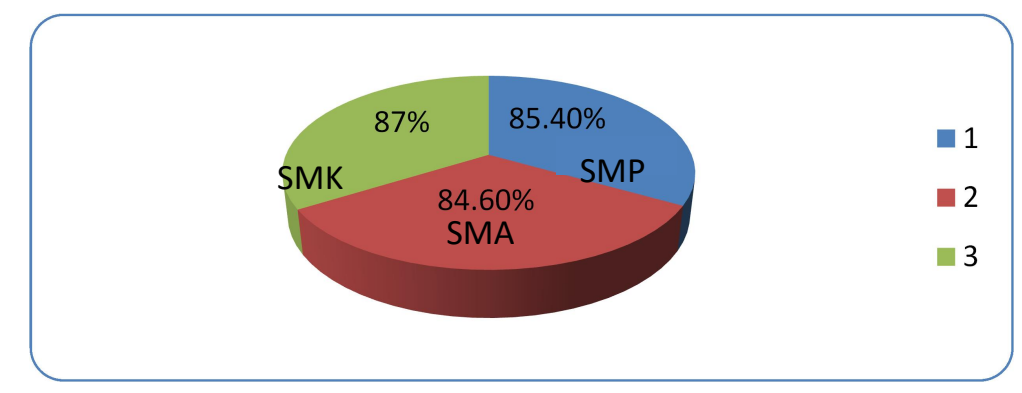

Berdasarkan data dalam diagram pie 4.3, dapat disimpulkan, bahwa analisis deskriptif data pada tingkatan sekolah (SMP, SMA, SMK) Kota Gorontalo terhadap kualitas pendidikan agama Islam berbasis ICT, untuk tingkat SMP nilai data responden mencapai 85, 4\%, untuk SMA 84,6 \% dan SMK $87 \%$. Hasil porsentase yang dicapai dalam porsentase pada pada diagram pie 4.3 , tersebut, menunjukkan porsentase paling besar diberikan oleh tingkat SMK. Dengan demikian dapat diasumsikan, bahwa kualitas pendidikan agama Islam berbasis ICT di SMK, dinyatakan sangat baik dengan porsentase mencapai $87 \%$ dari prosentase $100 \%$ yang diharapkan, adapun perbedaan yang nampak pada tingkat sekolah SMP dan SMA pada SMK, mengalami perbedaan 0,33 = 33\% pada masing-masing tingkat sekolah dari rata-rata nilai skor ideal yaitu $=100 \%$, perbedaan yang terjadi disebabkan oleh faktor-faktor luar yang mempengaruhinya, diantaranya penyediaan fasilitas media pembelajaran ICT pada tingkat sekolah SMP, dan SMA yang belum merata pada setiap sekolah yang ada di Kota Gorontalo.

Hasil porsentase yang dicapai oleh tingkat sekolah SMK sebesar 87\%, menunjukkan bahwa pelaksanaan kegiatan ditinjau dari segi konteks, input proses dan produk pendidikan yang diselenggarakan disekolah terlaksana dengan baik dengan penyediaan fasilitas sarana dan prasarana yang memadai, seperti: (a) laboratrium ICT, (b) perpustakaan, (c) ruang belajar yang efesien, dan (d) pengelolaan manajemen sekolah seperti; tenaga pendidik yang propesional, pengembangan bahan ajar pendidikan agama Islam berbasis ICT pada proses pembelajaran, serta unsur penunjang pendidikan lainnya.

\section{Deskripsi Data Variabel Persepsi Guru PAI Terhadap Pendidikan Agama Islam Berbasis ICT Di era MEA.}

Berdasarkan hasil data pengolahan nilai, harga porsentase yang diberikan yang diperoleh sebesar $=80 \%$. Dari skor $100 \%$ yang diharapkan. Dengan ketentuan jumlah skor ideal yang diharapkan sebesar $=5.185$. Berdasarkan hasil pengolahan data, maka dapat disimpulkan bahwa persepsi guru PAI terhadap pendidikan agama Islam berbasis ICT di era MEA berada pada posisi yang baik, hal ini menunjukkan bahwa persepsi atau padangan, perasaan, guru pendidikan agama Islam (PAI) merespon baik pendidikan dengan menerapkan pendidikan agama Islam berbasis ICT di sekolah Kota Gorontalo.

Untuk mendeskiprisikan hasil pengumpulan data pada variabel persepsi guru PAI terhadap pendidikan agama Islam berbasis ICT di era MEA, lebih rinci 
lagi akan dideskripsikan pada setiap indikator dalam dimensi persepsi guru PAI terhadap pendidikan agama islam berbasis ICT di era MEA, sebagai berikut:

\subsection{Analisis Deskiptif Kuantitatif Pada Dimensi Dan Indikator Persepsi Guru PAI Terhadap PAI berbasis ICT diera MEA \\ 1) Dimensi Sikap Rasa Ingin Tahu}

. Untuk lebih jelasnya analisis dimensi sikap rasa ingin tahu dan indikatornya disajikan pada tabel berikut:

Tabel 4.7: Analisis Dimensi Rasa Ingin Tahu dan Indikator pada Variabel Persepsi guru PAI terhadap Pendidikan agama Islam berbasis ICT di Era MEA.

\begin{tabular}{|c|l|c|}
\hline No & \multicolumn{1}{|c|}{ Indikator } & $\begin{array}{c}\text { Porsentase } \\
\text { skor }\end{array}$ \\
\hline 1 & Memiliki rasa ingin tahu tentang MEA & $76,7 \%$ \\
\hline 2 & Merasa tertarik dengan trend MEA & $81,3 \%$ \\
\hline 3 & Memiliki ide dan gagasan tertentu & $80,7 \%$ \\
\hline 4 & $\begin{array}{l}\text { Memiliki sikap terbuka terhadap perubahan dan } \\
\text { kebijakan }\end{array}$ & $75,7 \%$ \\
\hline 5 & Mau mencoba hal-hal yang dijumpai & $83,3 \%$ \\
\hline \multicolumn{2}{|c|}{ Posentase total } & $\mathbf{7 9 , 5 \%}$ \\
\hline
\end{tabular}

Pada tabel 4.7 tersebut data kuantitatif menunjukan harga porsentase dimensi sikap rasa ingin tahu sebesar $=79,5 \%$. Dengan demikian bahwa sikap guru PAI dalam memberikan pandangan atau perasaan terhadap pendidikan agama Islam berbasis ICT di era MEA menunjukkan deskripsi rasa ingin tahu yang mengambarkan sikap merespon perubahan-perubahan yang terjadi saat sekarang melalui informasi yang didengar, dibaca, dan diketahui berdasarkan sumber yang benar dan jelas seperti; media cetak dan media sosial. Dimensi rasa ingn tahu guru PAI terhadap pendidikan agama Islam berbasis ICT diera MEA berada pada kategori cukup. Dengan harga posentase yang dicapai sebesar $=$ $79,5 \%$.

\section{2) Dimensi Sikap Mau Menerima Tantangan}

. Untuk lebih jelasnya analisis dimensi merasakan adanya tantangan dan indikatornya disajikan pada tabel berikut:

Tabel 4.8: Analisis Dimensi Sikap Mau Menerima Tantangan Dan Indikator Pada Variabel Persepsi Guru PAI Terhadap Pendidikan agama Islam berbasis ICT di era MEA.

\begin{tabular}{|l|l|c|}
\hline No & \multicolumn{1}{|c|}{ Indikator } & Porsentase skor \\
\hline 1 & $\begin{array}{l}\text { Memahami kekurangan dan } \\
\text { kelebihan diri dalam berbuat }\end{array}$ & $88,5 \%$ \\
\hline 2 & $\begin{array}{l}\text { Mampu menanggapi } \\
\text { permasalahan yang sulit }\end{array}$ & $80,3 \%$ \\
\hline $\begin{array}{l}\text { Posentase total dimensi menerima } \\
\text { tantang dalam MEA }\end{array}$ & $84,4 \%$ \\
\hline
\end{tabular}

Berdasarkan tabel 4.8 dapat disimpulkan bahwa analisis data menunjukan guru PAI di Kota Gorontalo, mengetahui dan memahami kekurangan dan 
kelebihan diri dalam bertindak dan melakukan sesuatu, dengan harga porsentase yang diberikan adalah sebesar $=88,5 \%$. Sementara itu persepsi guru PAI dalam memberikan pandangan dan perasaan terhadap permasalahan-permasalahan yang muncul dalam pendidikan disekolah di Kota Gorontalo memberikan respon sebesar $=80,3 \%$ dari nilai $100 \%$ yang diharapkan. Dengan demikian deskripsi tentang merasakan adanya tantangan dalam persepsi guru PAI terhadap pendidikan agama Islam berbasis ICT di era MEA, menggambarkan sikap guru PAI dalam melihat kekurangan-kekurangan diri dalam proses pembelajaran dan selanjutnya melakukan perubahan kepada arah yang lebih baik, serta selalu mengetahui, melibatkan diri untuk masalah-masalah yang sulit dalam pendidikan dan memberikan solusi terhadap permasalahan tersebut berada pada kategori sangat baik dengan harga porsentase yang diperoleh $=84,4 \%$.

\section{3) Dimensi Memiliki Sikap Imajinatif}

Tabel 4.9: Analisis Dimensi Sikap memiliki Imajinatif Dan Indikator pada Variabel Persepsi guru PAI terhadap pendidikan agama Islam berbasis ICT di Era MEA.

\begin{tabular}{|l|l|c|}
\hline No & \multicolumn{1}{|c|}{ Indikator } & Porsentase \\
\hline 1 & $\begin{array}{l}\text { Membayangkan pola hidup dan seluruh aktivitas orang di era } \\
\text { MEA }\end{array}$ & $80,0 \%$ \\
\hline 2 & Memiliki firasat/dugaan yang kuat terhadap sesuatu & $84,3 \%$ \\
\hline 3 & Memiliki angan-angan dan kenyataan hidup & $77,4 \%$ \\
\hline 4 & Membayangkan sesuatu yang diluar kenyataan & $79,0 \%$ \\
\hline 5 & Berani mengambil resiko & $75,7 \%$ \\
\hline \multicolumn{2}{|l|}{ Posentase total dimensi proses } & $79,2 \%$ \\
\hline
\end{tabular}

Berdasarkan tabel 4.9 dapat disimpulkan persepsi guru PAI pada dimensi Imajinatif menunjukkan guru PAI mampu menggambarkan sesuatu dengan dugaan yang kuat serta mampu membayangkan sesuatu yang belum pernah terjadi yang selanjutnya dapat diwujudkan dalam suatu kenyataan, dan mau untuk menjejejaki hal-hal yang baru dalam pendidikan. Dengan harga porsentase yang diberikan sebesar 79,2 \% termasuk pada kategori cukup.

4) Intelektual

Tabel 4.10: Analisis Dimensi pengetahuan guru PAI(Intelektual)Dan Indikator Pada Variabel Persepsi guru PAI terhadap Pendidikan agama Islam berbasis ICT di era MEA.

\begin{tabular}{|c|l|c|}
\hline No & \multicolumn{1}{|c|}{ Indikator } & Porsentase \\
\hline 1 & Berpikir lancar & $79,0 \%$ \\
\hline 2 & Berpikir luwes & $85,9 \%$ \\
\hline 3 & Berpikir orisinil & $84,6 \%$ \\
\hline 4 & Berpikir terperinci & $82,1 \%$ \\
\hline \multicolumn{2}{|c|}{ Posentase total } & $82,7 \%$ \\
\hline
\end{tabular}


Dari tabel 4.10 dapat disimpulkan analisis data kuantitatif menunjukan guru PAI pada disekolah SMP, SMA dan SMK Kota Gorontalo dalam berpikir menghasilkan jawaban yang relevan, mampu berpikir untuk memberikan gagasan dan jawaban yang berbeda serta mau mengubah cara berpikir untuk memahami proses pendidikan agama Islam berbasis ICT diera MEA serta memiliki intelektual yang mampu mencetak keterampilan dan kompetensi siswa dalam pendidikan dengan berbaasis teknologi pendidikan masa depan agar mampu bersaing di era trend MEA, memberikan persepsi pengetahuan sebesar $=82,7 \%$. Dengan demikian deskripsi tentang dimensi intelektual menurut persepsi guru PAI terhadap pendidikan agama Islam berbasis ICT di era MEA termasuk pada posisi sangat baik, dengan porsentase mencapai $82,7 \%$.

\subsection{Analisis Seluruh Dimensi Persepsi Guru PAI Terhadap PAI Berbasis ICT.}

Berdasarkan analisis seluruh dimensi pada variabel persepsi guru PAI terhadap pendidikan agama Islam berbasis ICT diera MEA secara keseluruhan, dapat disimpulkan bahwa hasil pengolahan data dan analisis data harga porsentase capaian berada pada posisi yang sangat kuat dengan rata-rata $=81,4$ \%.Hasil Analisis dan pengolahan data seluruh dimensi sikap dan pengetahuan guru PAI yaitu: (1) rasa ingin tahu, (2) mau menerima tantangan, (3) imajinatif dan (4) intelektual, untuk mengukur persepsi padangan sikap dan pengetahuan guru PAI di sekolah di Kota Gorontalo, disajikan melalui diagram berikut:

Diagram Batang 4.7:Analisis Seluruh Dimensi Variabel Persepsi guru PAI Terhadap Pendidikan agama Islam berbasis ICT di Era MEA.

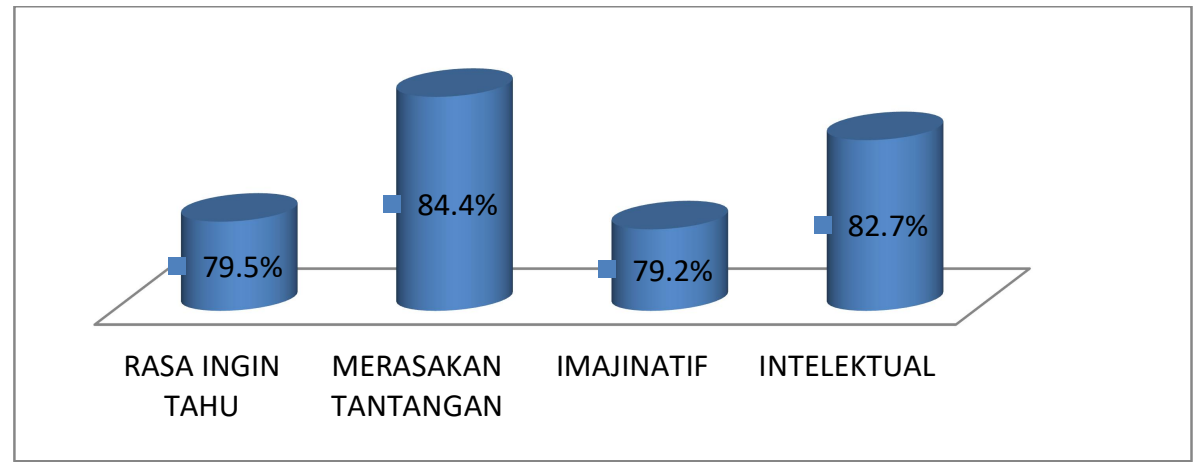

Berdasarkan hasil analisis pada diagram batang 4.4 dapat disimpulkan, dimensi dalam sikap rasa ingin tahu tentang pendidikan dalam MEA memberikan porsentase sebesar 79,5\%, merasakan tantangan sebesar 84,4\%, guru PAI harus memiliki imajinatif dalam proses pendidikan berbasis ICT di era MEA memberikan respon sebesar $79,2 \%$ serta berintelektual yang tinggi memberikan respon sebesar $82,7 \%$. Dari porsentase nilai yang diberikan oleh responden guru PAI, secara keseluruhan mencapai $81,45 \%$ maka pengukuran untuk variabel persepsi guru PAI terhadap pendidikan agama Islam berbasis ICT di era MEA berada pada posisi yang sangat kuat, dengan presepsi bahwa memiliki rasa ingin tahu, mau menerima tantangan, bersikap imajinatif dan bersikap intelektual merupakan bentuk sikap dan pengetahuan guru PAI yang dapat diukur untuk 
mengetahui kualitas pendidikan agama Islam berbasis ICT di era MEA yang syarat dengan kemajuan ICT.

Rangkuman hasil perhitungan besar koefesien korelasi sederhana anatar variabel penelitian, seperti yang disajikan dalam matrik berikut:

Tabel 4.6. Matriks koefesien korelasi Sederhana antar Varibel

\begin{tabular}{|l|c|c|}
\hline \multicolumn{1}{|c|}{ Variabel } & Persepsi guru PAI & Kualitas Pendidikan \\
\hline Persepsi Guru PAI & & $0,993^{*}$ \\
\hline Kualitas Pendidikan & $0,62^{*}$ & \\
\hline
\end{tabular}

- $\quad$ Signifikan pada $\infty 0,05\left(\mathrm{r}_{\text {tabel }}=0,254\right)$

Setelah diperoleh nilai koefesien sederhana maka dilanjutkan dengan uji signifkan dengan menggunakan uji-t

Tabel 4.7 pengujian Hipotesis

\begin{tabular}{|l|l|l|l|l|l|}
\hline \multicolumn{1}{|c|}{ Hipotesis } & Uji statistik & $\mathrm{t}_{\text {hitung }}$ & $\mathrm{dk}(\mathrm{n}-1)$ & $\mathrm{t}_{\text {tabel }(\alpha=0,05)}$ & Kesimpulan \\
\hline $\begin{array}{l}\text { 1. Kualitas } \\
\text { pendidikan paling } \\
\text { tinggi } 80 \%\end{array}$ & $\begin{array}{l}\text { Ha: } \mu o<180 \\
\text { Ho: } \mu \mathrm{o}>180\end{array}$ & 72,3 & 60 & 1,671 & Ha ditolak \\
2. Persepsi guru PAI & $\begin{array}{l}\text { Ha: } \mu o>59,5 \\
\text { Ho: } \mu o<59,5\end{array}$ & 11,92 & 60 & 1,671 & Ho ditolak \\
\hline
\end{tabular}

Dari tabel diatas No 1. Dapat disimpulkan hipotesis menyatakan bahwa, Ha: Kualitas pendidikan agama Islam berbasis ICT disekolah Kota Gorontalo paling tinggi $80 \%$ dari rata-rata nilai ideal ditolak Ho:(kualitas pendidikan agama Islam berbasis ICT paling rendah $80 \%$ dari rata-rata nilai ideal diterima). Jadi kualitas pendidikan agama Islam tahun 2016 paling tinggi $80 \%$ dari rata-rata nilai ideal ditolak bahkan lebih dari nilai $80 \%$ dari apa yang diduga, atau terdapat perbedaan antara yang diduga dalam populasi dengan data yang terkumpul dari sampel. Hasil perhitungan terhadap data sampel diperoleh nilai kualitas pendidikan agama Islam berbasis ICT $=85,7 \%$ atau lebih dari $80 \%$ nilai yang dihipotesiskan.

Dari tabel No.2.Dapat disimpulkan bahwa hipotesis yang menyatakan bahwa Ha: persepsi guru PAI terhadap pendidikan agama Islam berbasis ICT di era MEA di Kota Gorontalo tahun 2016 paling rendah 70\% dari rata-rata nilai ideal diterima, sedangkan Ho: yang menyatakan bahwa:persepsi guru PAI paling tinggi $70 \%$ dari rata-rata nilai idel ditolak. Jadi persepsi guru PAI terhadap pendidikan agama Islam berbasis ICT di Kota Gorontalo tahun 2016 paling rendah $70 \%$ dari rata-rata nilai ideal itu benar. Hasil perhitungan terhadap data sampel diperoleh nilai persepsi guru PAI terhadap pendidikan agama Islam berbasis ICT di Kota Gorontalo $=80,9 \%$ lebih dari 70\%. Dengan demikian dapat disimpulkan bahwa persepsi guru PAI terhadap pendidikan agama Islam berbasis ICT di era MEA di Kota Gorontalo pada tahun 2016 lebih lebih baik dari sebelumnya dan merupakan salah satu varian yang mempengaruhi kualitas pendidikan agama Islam berbasis ICT di Kota Gorontalo.

Analisis Gabungan (Mixed Methods).

a. Analisis Data Kuantitatif dan Kualitatif

1) Variabel Kualitas Pendidikan Agama Islam berbasis ICT. 
Analisis data kuantitatif dan kualitatif dilakukan untuk membandingkan kedua data melalui hasil penelitian pada tahap pertama dan tahap kedua. Melalui kedua tahap penelitian, analisis data yang dilakukan untuk memberikan informasi apakah kedua data tersebut saling melengkapi, memperluas, memperdalam atau malah bertentangan satu dengan lainnya. Perbandingan data analisis kuantitatif dan kualitatif variabel kualitas pendidikan agama Islam berbasis ICT disajikan dalam tabel berikut:

Tabel 4.12: Perbandingan data Kuantitatif dan Kualitatif Variabel Kualitas PAI berbasis ICT.

\begin{tabular}{|c|c|c|c|c|}
\hline $\begin{array}{l}\mathbf{N} \\
\mathbf{0}\end{array}$ & $\begin{array}{l}\text { Butir Soal } \\
\text { /Kategori }\end{array}$ & $\begin{array}{c}\text { Data } \\
\text { Kuan } \\
\text { titatif } \\
(\%) \\
\end{array}$ & Data Kualitatif & Kesimpulan \\
\hline 1 & $\begin{array}{l}\text { Informasi } \\
\text { penggunaan } \\
\text { ICT disekolah }\end{array}$ & $88,9 \%$ & $\begin{array}{l}\text { Di seluruh sekolah, SMP, SMA, } \\
\text { SMK telah menggunakan system } \\
\text { Pendidikan berbasis ICT. }\end{array}$ & $\begin{array}{l}\text { Memperluas } \\
\text { dan } \\
\text { memperdalam } \\
\text { data kuantitatif }\end{array}$ \\
\hline 2 & $\begin{array}{l}\text { Peningkatan } \\
\text { mutu } \\
\text { pendidikan } \\
\text { melalui } \\
\text { pendidikan } \\
\text { berbasis ICT }\end{array}$ & $88,9 \%$ & $\begin{array}{ll}\text { Pendidikan saat ini lebih } \\
\text { mementingkan peningkatan mutu/ } \\
\text { kualitas pendidikan, dengan } \\
\text { mengembangkan } & \text { konsep } \\
\text { pendidikan berbasis ICT. } & \end{array}$ & $\begin{array}{l}\text { Memperluas } \\
\text { dan } \\
\text { memperdalam } \\
\text { data kuantitatif }\end{array}$ \\
\hline 3 & $\begin{array}{l}\text { Melaksanakan } \\
\text { Visi dan Misi } \\
\text { Pendidikan } \\
\text { berbasis ICT }\end{array}$ & $85,6 \%$ & $\begin{array}{l}\text { Visi-dan Misi setiap sekolah } \\
\text { searah dengan perkembangan } \\
\text { teknologi atau pendidikan berbasis } \\
\text { ICT/ IPTEK }\end{array}$ & $\begin{array}{l}\text { Memperluas } \\
\text { dan } \\
\text { memperdalam } \\
\text { data kuantitatif }\end{array}$ \\
\hline 4 & $\begin{array}{l}\text { Peran Kepala } \\
\text { sekolah dan } \\
\text { guru pada } \\
\text { pendidikan } \\
\text { berbasis ICT }\end{array}$ & $87,5 \%$ & $\begin{array}{l}\text { Kepala sekolah selalu } \\
\text { menghimbau kepada setiap guru } \\
\text { untuk selalu mengusai ICT dalam } \\
\text { Pendidikan. }\end{array}$ & $\begin{array}{l}\text { Memperluas } \\
\text { dan } \\
\text { memperdalam } \\
\text { data kuantitatif }\end{array}$ \\
\hline 5 & $\begin{array}{l}\text { Dukungan } \\
\text { pengembangan } \\
\text { pendidikan } \\
\text { berbasis ICT } \\
\text { dari pemerintah } \\
\text { dan orang tua }\end{array}$ & $4,6 \%$ & $\begin{array}{l}\text { Dalam pengembangan pendidikan } \\
\text { berbasis ICT disekolah dukungan } \\
\text { pemerintah kota Gorontalo } \\
\text { merupakan garda yang terdepan } \\
\text { untuk kemajuan pendidikan, } \\
\text { begitu juga dengan bantuan orang } \\
\text { tua siswa dalam mensukseskan } \\
\text { pendidikan berbasis ICT di Kota } \\
\text { Gorontalo. }\end{array}$ & $\begin{array}{l}\text { Memperluas } \\
\text { dan } \\
\text { memperdalam } \\
\text { data kuantitatif }\end{array}$ \\
\hline 6 & $\begin{array}{l}\text { Perencanaan } \\
\text { program } \\
\text { unggulan dan } \\
\text { rencana } \\
\text { strategis } \\
\end{array}$ & $2 \%$ & $\begin{array}{l}\text { perencanaan program pendidikan } \\
\text { Agama Islam berbasis ICT, } \\
\text { sementara ini masih ditempuh } \\
\text { dengan cara siswa belajar dengan } \\
\text { media ICT didalam kelas dan }\end{array}$ & $\begin{array}{l}\text { Memperluas } \\
\text { dan } \\
\text { memperdalam } \\
\text { data kuantitatif }\end{array}$ \\
\hline
\end{tabular}




\begin{tabular}{|c|c|c|c|c|}
\hline & & & $\begin{array}{l}\text { secara on-line siswa dapat } \\
\text { berkomunikasi lewat e-mail guru } \\
\text { PAI untuk mengirim tugas-tugas } \\
\text { sekolah yang berhubungan dengan } \\
\text { pendidikan, melalui fasilitas } \\
\text { internet sekolah. }\end{array}$ & \\
\hline 7 & $\begin{array}{l}\text { Pengawasan dan } \\
\text { evaluasi } \\
\text { program } \\
\text { pendidikan } \\
\text { berbasis ICT }\end{array}$ & $84,3 \%$ & $\begin{array}{l}\text { Kepala sekolah } \\
\text { pembeliajaran, triwulan } \\
\text { evaluasi dan } \\
\text { pendidikan. }\end{array}$ & $\begin{array}{l}\text { Memperluas } \\
\text { dan } \\
\text { memperdalam } \\
\text { data kuantitatif }\end{array}$ \\
\hline 8 & $\begin{array}{l}\text { Laporan } \\
\text { kemajuan } \\
\text { sekolah dalam } \\
\text { bidang ICT }\end{array}$ & $84,3 \%$ & $\begin{array}{l}\text { Melaporkan ke DIKNAS setempat } \\
\text { seluruh kebutuhan fasilitas ICT } \\
\text { dan hasil belajar siswa } \\
\text { menggunakan ICT pada seluruh } \\
\text { mata pelajaran. }\end{array}$ & $\begin{array}{l}\text { Memperluas } \\
\text { dan } \\
\text { memperdalam } \\
\text { data kuantitatif }\end{array}$ \\
\hline 9 & $\begin{array}{l}\text { pembiyaan } \\
\text { pendidikan } \\
\text { Berbasis ICT } \\
\text { disekolah }\end{array}$ & $83,6 \%$ & $\begin{array}{l}\text { Pembiyaan-pembiyaan sekolah } \\
\text { dalam pendidikan berbasis ICT } \\
\text { disesuaikan dengan mata anggaran } \\
\text { bantuan pemerintah dan } \\
\text { pengadaaan fasilitas, selain } \\
\text { diharapkan dari bantuan orang tua. }\end{array}$ & $\begin{array}{l}\text { Memperluas } \\
\text { dan } \\
\text { memperdalam } \\
\text { data kuantitatif }\end{array}$ \\
\hline $\begin{array}{l}1 \\
0\end{array}$ & $\begin{array}{l}\text { SOP } \\
\text { Penyelenggaraa } \\
\text { n pendidikan } \\
\text { sekolah }\end{array}$ & $83,0 \%$ & $\begin{array}{l}\text { Setiap pelakasanaan program } \\
\text { sekolah harus berdasarkan SOP } \\
\text { pendidikan disekolah. }\end{array}$ & $\begin{array}{l}\text { Memperluas } \\
\text { dan } \\
\text { memperdalam } \\
\text { data kuantitatif }\end{array}$ \\
\hline $\begin{array}{l}1 \\
1\end{array}$ & $\begin{array}{l}\text { Standar } \\
\text { Kualifikasi } \\
\text { pendidikan } \\
\text { untuk pendidik }\end{array}$ & $85,2 \%$ & $\begin{array}{l}\text { Mewujudkan sekolah } \text { yang } \\
\text { bermutu dalam ICT, maka } \\
\text { kualifikasi pendidik di tingkat } \\
\text { SMP, SMA dan SMK harus } \\
\text { berpendidikan sarjana (S1) dan } \\
\text { diupayakan sampai (S2) serta } \\
\text { memiliki kompetensi. }\end{array}$ & $\begin{array}{l}\text { Memperluas } \\
\text { dan } \\
\text { memperdalam } \\
\text { data kuantitatif }\end{array}$ \\
\hline $\begin{array}{l}1 \\
2\end{array}$ & $\begin{array}{l}\text { Perlunya } \\
\text { kompetensi dan } \\
\text { berijasah } \\
\text { minimal S1 dan } \\
\text { menguasai ICT }\end{array}$ & $86,2 \%$ & $\begin{array}{l}\text { Sekolah dengan system } \\
\text { pendidikan berbasis ICT, memiliki } \\
\text { syarat untuk seorang pendidik } \\
\text { harus memiliki kompetensi } \\
\text { minimal S1 dan menguasai ICT. }\end{array}$ & $\begin{array}{l}\text { Memperluas } \\
\text { dan } \\
\text { memperdalam } \\
\text { data kuantitatif }\end{array}$ \\
\hline $\begin{array}{l}1 \\
3\end{array}$ & $\begin{array}{l}\text { Kemampuan } \\
\text { rata-rata guru } \\
\text { PAI dalam ICT }\end{array}$ & $86,2 \%$ & $\begin{array}{l}\text { Percaya dengan kemampuan guru, } \\
\text { hampir semua guru mengusai ICT } \\
\text { pada taraf pengoperasionalan } \\
\text { komputer dalam pendidikan, }\end{array}$ & $\begin{array}{l}\text { Memperluas } \\
\text { dan } \\
\text { memperdalam } \\
\text { data kuantitatif }\end{array}$ \\
\hline
\end{tabular}




\begin{tabular}{|c|c|c|c|c|}
\hline 1 & $\begin{array}{l}\text { Kesiapan sarana } \\
\text { dan prasarana } \\
\text { pendidikan } \\
\text { berbasis ICT }\end{array}$ & $1,6 \%$ & $\begin{array}{l}\text { Sarana dan prasana ICT yang } \\
\text { harus disiapkan memenuhi standar } \\
\text { dalam pendidikan pada umumnya } \\
\text { minimal dalam proses } \\
\text { pembelajaran seperti laptop, atau } \\
\text { PC dan LCD/ proyektor. }\end{array}$ & $\begin{array}{l}\text { Memperluas } \\
\text { dan } \\
\text { memperdalam } \\
\text { data kuantitatif }\end{array}$ \\
\hline $\begin{array}{l}1 \\
5\end{array}$ & $\begin{array}{l}\text { Standar ruangan } \\
\text { belajar untuk } \\
\text { pendididkan } \\
\text { berbasis ICT } \\
\text { disekolah }\end{array}$ & $84,9 \%$ & $\begin{array}{l}\text { Standar ruang belajar harus sesuai } \\
\text { dengan kebutuhan pendidikan, } \\
\text { ukuran ruangan berstandar } \\
\text { nasional, serta kondusif dalam } \\
\text { penggunaannya, serta lengkap } \\
\text { dengan peralatan media ICT. }\end{array}$ & $\begin{array}{l}\text { Memperluas } \\
\text { dan } \\
\text { memperdalam } \\
\text { data kuantitatif }\end{array}$ \\
\hline $\begin{array}{l}1 \\
6\end{array}$ & $\begin{array}{l}\text { Fungsi } \\
\text { laboratrium } \\
\text { pada pendidikan } \\
\text { PAI berbasis } \\
\text { ICT disekolah }\end{array}$ & $5,9 \%$ & $\begin{array}{l}\text { Fungsi Laboratrium PAI berbasis } \\
\text { ICT sebagai tempat untuk } \\
\text { mengetahui dan memperkenalkan } \\
\text { kemajuan bidang ICT lainnya } \\
\text { seperti, perkembagan kemajuan } \\
\text { Pembuatan program pendidikan. }\end{array}$ & $\begin{array}{l}\text { Memperluas } \\
\text { dan } \\
\text { memperdalam } \\
\text { data kuantitatif }\end{array}$ \\
\hline $\begin{array}{l}1 \\
7\end{array}$ & $\begin{array}{l}\text { Fungsi } \\
\text { perpustakaan } \\
\text { dalam } \\
\text { pendidikan } \\
\text { berbasis ICT } \\
\text { disekolah }\end{array}$ & $5,2 \%$ & $\begin{array}{l}\text { perpustakaan sebagai penunjang } \\
\text { pendidikan siswa, sebagai sumber } \\
\text { belajar dengan literature-literatur } \\
\text { yang diperlukan }\end{array}$ & $\begin{array}{l}\text { Memperluas } \\
\text { dan } \\
\text { memperdalam } \\
\text { data kuantitatif }\end{array}$ \\
\hline $\begin{array}{l}1 \\
8\end{array}$ & $\begin{array}{l}\text { Syarat yang } \\
\text { standarkan } \\
\text { dalam } \\
\text { kualifikasi dan } \\
\text { rekrutmen } \\
\text { tenaga teknisi } \\
\text { Lab, ICT }\end{array}$ & $84,6 \%$ & $\begin{array}{l}\text { Standar kualifikasi bagi seorang } \\
\text { teknisi LAB, } \\
\text { berpenddikan minimal } \\
\text { berkompetensi, dan yang lebih } \\
\text { utama adalah mengusai ICT serta } \\
\text { dapat memotivasi siswa untuk } \\
\text { berinovasi dalam ICT pendidikan. }\end{array}$ & $\begin{array}{l}\text { Memperluas } \\
\text { dan } \\
\text { memperdalam } \\
\text { data kuantitatif }\end{array}$ \\
\hline $\begin{array}{l}1 \\
9\end{array}$ & $\begin{array}{l}\text { Target belajar } \\
\text { PAI berbasis } \\
\text { ICT yang } \\
\text { effektif }\end{array}$ & $87,2 \%$ & $\begin{array}{l}\text { Target effektif dalam proses } \\
\text { pembelajaran PAI berbasis ICT } \\
\text { diharapkan siswa dapat } \\
\text { mengoperasikan komputer dalam } \\
\text { mempresentasikan tugas dari guru } \\
\text { dan menggunakannya secara } \\
\text { Islami. }\end{array}$ & $\begin{array}{l}\text { Memperluas } \\
\text { dan } \\
\text { memperdalam } \\
\text { data kuantitatif }\end{array}$ \\
\hline $\begin{array}{l}2 \\
0\end{array}$ & $\begin{array}{l}\text { Membuat bahan } \\
\text { ajar yang } \\
\text { menarik }\end{array}$ & 86,6 & $\begin{array}{l}\text { Guru menyusun bahan ajar sesuai } \\
\text { dengan materi yang akan } \\
\text { disampaikan, semenarik mungkin } \\
\text { untuk ditampilkan. }\end{array}$ & $\begin{array}{l}\text { Memperluas } \\
\text { dan } \\
\text { memperdalam } \\
\text { data kuantitatif }\end{array}$ \\
\hline $\begin{array}{l}2 \\
1\end{array}$ & $\begin{array}{l}\text { Metode } \\
\text { pembelajaran } \\
\text { berbasis ICT } \\
\text { yang bervariasi }\end{array}$ &,$+ 0 \%$ & $\begin{array}{l}\text { Menggunakan } \\
\text { pembelajaran yang bervariasi } \\
\text { berbasis ICT, seperti; metode } \\
\text { belajar menganalisis tayangan }\end{array}$ & $\begin{array}{l}\text { Memperluas } \\
\text { dan } \\
\text { memperdalam } \\
\text { data kuantitatif }\end{array}$ \\
\hline
\end{tabular}




\begin{tabular}{|c|c|c|c|c|}
\hline & & & $\begin{array}{l}\text { film-film Islami, menjawab quis } \\
\text { melalui program mainan soal } \\
\text { jawab dan variasi program ICT } \\
\text { lainnya yang menarik bagi siswa. }\end{array}$ & \\
\hline $\begin{array}{l}2 \\
2\end{array}$ & $\begin{array}{l}\text { Mempresentasik } \\
\text { an bahan ajar } \\
\text { yang inovatif } \\
\text { dan kreatif } \\
\text { berbasis ICT }\end{array}$ & $85,2 \%$ & $\begin{array}{l}\text { Bahan ajar yang dipresentasikan } \\
\text { adalah bahan ajar yang inovatif } \\
\text { dan kreatif buatan sendiri. }\end{array}$ & $\begin{array}{l}\text { Memperluas } \\
\text { dan } \\
\text { memperdalam } \\
\text { data kuantitatif }\end{array}$ \\
\hline $\begin{array}{l}2 \\
3\end{array}$ & $\begin{array}{l}\text { Menggunakan } \\
\text { media } \\
\text { pembelajaran } \\
\text { berbasis ICT } \\
\text { dalam } \\
\text { pembelajaran }\end{array}$ & $86,6 \%$ & $\begin{array}{l}\text { Guru menggunakan media } \\
\text { pembelajaran berbasis ICT pada } \\
\text { materi-materi tertentu, }\end{array}$ & $\begin{array}{l}\text { Memperluas } \\
\text { dan } \\
\text { memperdalam } \\
\text { data kuantitatif }\end{array}$ \\
\hline $\begin{array}{l}2 \\
4\end{array}$ & $\begin{array}{l}\text { Mendesain } \\
\text { materi yang } \\
\text { inovatif dan } \\
\text { kreatif }\end{array}$ & $82,0 \%$ & $\begin{array}{l}\text { Membuat materi PAI agar menarik } \\
\text { ditampilkan didepan kelas, guru } \\
\text { mendesain materi dengan kreatif } \\
\text { dan inovatif dengan memadukan } \\
\text { berbagai jenis } \\
\text { pembelajaran. }\end{array}$ & $\begin{array}{l}\text { Memperluas } \\
\text { dan } \\
\text { memperdalam } \\
\text { data kuantitatif }\end{array}$ \\
\hline $\begin{array}{l}2 \\
5\end{array}$ & $\begin{array}{l}\text { Pengelolaan } \\
\text { kelas yang } \\
\text { effektif dan } \\
\text { kondusif pada } \\
\text { proses } \\
\text { pembelajaran } \\
\text { berbasis ICT }\end{array}$ & $4,6 \%$ & $\begin{array}{l}\text { Menciptakan suasana belajar yang } \\
\text { berinteraksi satu dengan lainnya, } \\
\text { dalam pembelajaran PAI berbasis } \\
\text { ICT dilakukan secara } \\
\text { berkelompok, dan secara klasikal, } \\
\text { sesuai dengan kebutuhan materi } \\
\text { yang akan disampaikan. }\end{array}$ & $\begin{array}{l}\text { Memperluas } \\
\text { dan } \\
\text { memperdalam } \\
\text { data kuantitatif }\end{array}$ \\
\hline $\begin{array}{l}2 \\
6\end{array}$ & $\begin{array}{l}\text { Implementasi } \\
\text { proses } \\
\text { pembelajaran } \\
\text { ICT untuk } \\
\text { mengikuti even } \\
\text { /lomba } \\
\text { pendidikan } \\
\text { berbasis ICT }\end{array}$ & $85,9 \%$ & $\begin{array}{l}\text { Perlombaan siswa seperti LKS } \\
\text { (lomba Kompetensi Siswa) dalam } \\
\text { bidang ICT khusus PAI siswa } \\
\text { selalu mengikutsrtakan siswa. }\end{array}$ & $\begin{array}{l}\text { Memperluas } \\
\text { dan } \\
\text { memperdalam } \\
\text { data kuantitatif }\end{array}$ \\
\hline $\begin{array}{l}2 \\
7\end{array}$ & $\begin{array}{l}\text { Perkembangan } \\
\text { siswa dalam } \\
\text { ICT melalui } \\
\text { proses penilaian } \\
\text { dan kinerja }\end{array}$ & $93,1 \%$ & $\begin{array}{l}\text { Perkembangan siswa dalam } \\
\text { bidang ICT khususnya dalam PAI, } \\
\text { dapat terukur melalui tugas-tugas } \\
\text { mempresentasikan materi PAI } \\
\text { secara kelompok dan individu } \\
\text { siswa. }\end{array}$ & $\begin{array}{l}\text { Memperluas } \\
\text { dan } \\
\text { memperdalam } \\
\text { data kuantitatif }\end{array}$ \\
\hline $\begin{array}{l}2 \\
8\end{array}$ & $\begin{array}{l}\text { Penaggulangan } \\
\text { masalah belajar } \\
\text { siswa dalam } \\
\end{array}$ & $91,8 \%$ & $\begin{array}{l}\text { Siswa yang bermasalah dalam ICT } \\
\text { diakadakan bimbingan dan latihan } \\
\text { secara berkala melalui kelompok- }\end{array}$ & $\begin{array}{l}\text { Memperluas } \\
\text { dan } \\
\text { memperdalam }\end{array}$ \\
\hline
\end{tabular}




\begin{tabular}{|c|c|c|c|c|}
\hline & $\begin{array}{l}\text { pendidikan } \\
\text { berbasis ICT. }\end{array}$ & & kelompok belajar siswa disekolah. & data kuantitatif \\
\hline $\begin{array}{l}2 \\
9\end{array}$ & $\begin{array}{l}\text { Kepribadian } \\
\text { guru PAI } \\
\text { dalam tugas } \\
\text { dan Ibadah }\end{array}$ & $91,1 \%$ & $\begin{array}{l}\text { Guru melakukan tugas dengan } \\
\text { baik dan taat beribadah }\end{array}$ & $\begin{array}{l}\text { Membuktikan, } \\
\text { Memperluas } \\
\text { dan } \\
\text { memperdalam } \\
\text { data kuantitatif }\end{array}$ \\
\hline $\begin{array}{l}3 \\
0\end{array}$ & 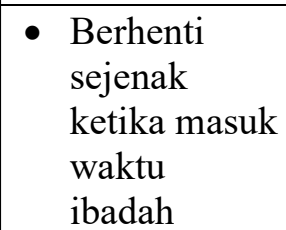 & $89,2 \%$ & $\begin{array}{l}\text { Guru bertingkah laku } \\
\text { menghentikan } \\
\text { pembelajaran ketika masuk waktu } \\
\text { ibadah }\end{array}$ & $\begin{array}{l}\text { Membuktikan, } \\
\text { Memperluas } \\
\text { dan } \\
\text { memperdalam } \\
\text { data kuantitatif }\end{array}$ \\
\hline $\begin{array}{l}3 \\
1\end{array}$ & $\begin{array}{l}\text { Mengajak } \\
\text { dan } \\
\text { mencontohk } \\
\text { an sikap } \\
\text { yang baik } \\
\text { dan benar }\end{array}$ & $91,1 \%$ & $\begin{array}{l}\text { Guru memerintahkan siswa untuk } \\
\text { melaksanakan ibadah menuju ke } \\
\text { masjid }\end{array}$ & $\begin{array}{l}\text { Membuktikan, } \\
\text { Memperluas } \\
\text { dan } \\
\text { memperdalam } \\
\text { data kuantitatif }\end{array}$ \\
\hline $\begin{array}{l}3 \\
2\end{array}$ & $\begin{array}{l}\text { - Disiplin } \\
\text { dalam tugas }\end{array}$ & $91,5 \%$ & $\begin{array}{l}\text { Guru selalu disiplin dan tepat } \\
\text { waktu dalm mengajar }\end{array}$ & $\begin{array}{l}\text { Membuktikan, } \\
\text { Memperluas } \\
\text { dan } \\
\text { memperdalam } \\
\text { data kuantitatif }\end{array}$ \\
\hline $\begin{array}{l}3 \\
3\end{array}$ & $\begin{array}{l}\text { Sopan } \\
\text { santun, } \\
\text { rendah hati } \\
\text { dan } \\
\text { bertingkah } \\
\text { laku baik } \\
\text { dan benar }\end{array}$ & $92,1 \%$ & $\begin{array}{l}\text { Guru bersikap sopan dan } \\
\text { bertingkah laku baik }\end{array}$ & $\begin{array}{l}\text { Membuktikan, } \\
\text { Memperluas } \\
\text { dan } \\
\text { memperdalam } \\
\text { data kuantitatif }\end{array}$ \\
\hline $\begin{array}{l}3 \\
4\end{array}$ & $\begin{array}{l}\text { - Menunjukka } \\
\text { n rasa kasih } \\
\text { sayang dan } \\
\text { hormat } \\
\text { terhadap } \\
\text { sesama }\end{array}$ & $92,1 \%$ & $\begin{array}{l}\text { Guru menunjukkan rasa kasih } \\
\text { sayang dan hormat terhadap } \\
\text { sesame }\end{array}$ & $\begin{array}{l}\text { Membuktikan, } \\
\text { Memperluas } \\
\text { dan } \\
\text { memperdalam } \\
\text { data kuantitatif }\end{array}$ \\
\hline $\begin{array}{l}3 \\
5\end{array}$ & $\begin{array}{l}\text { - } \text { Berpenampil } \\
\text { an menarik } \\
\text { dan } \\
\text { berpakain } \\
\text { sopan }\end{array}$ & $89,2 \%$ & $\begin{array}{l}\text { Guru berpenampilan } \\
\text { berpakian sopan dan rapi }\end{array}$ & $\begin{array}{l}\text { Membuktikan, } \\
\text { Memperluas } \\
\text { dan } \\
\text { memperdalam } \\
\text { data kuantitatif }\end{array}$ \\
\hline $\begin{array}{l}3 \\
6\end{array}$ & $\begin{array}{ll}\text { - } & \text { Mengikuti } \\
\text { aturan yang } \\
\text { telah } \\
\text { disepakati }\end{array}$ & $89,2 \%$ & $\begin{array}{l}\text { Guru selalu mengikuti aturan yang } \\
\text { diberlakukan disekolah }\end{array}$ & $\begin{array}{l}\text { Membuktikan, } \\
\text { Memperluas } \\
\text { dan } \\
\text { memperdalam }\end{array}$ \\
\hline
\end{tabular}




\begin{tabular}{|c|c|c|c|c|}
\hline & bersama & & & data kuantitatif \\
\hline $\begin{array}{l}3 \\
7\end{array}$ & $\begin{array}{ll}\text { - } & \text { Dapat } \\
\text { membedakan } \\
\text { kepentingan } \\
\text { pribadi dan } \\
\text { orang } \\
\text { banyak } \\
\end{array}$ & $93,4 \%$ & $\begin{array}{l}\text { Guru mampu membedakan } \\
\text { kepentingan pribadi dan orang } \\
\text { banyak }\end{array}$ & $\begin{array}{l}\text { Membuktikan, } \\
\text { Memperluas } \\
\text { dan } \\
\text { memperdalam } \\
\text { data kuantitatif }\end{array}$ \\
\hline $\begin{array}{l}3 \\
8\end{array}$ & \begin{tabular}{|l} 
Mengetahui \\
hak dan \\
kewajiban \\
dalam \\
bekerja \\
\end{tabular} & $89,2 \%$ & $\begin{array}{l}\text { Guru menaati hak dan } \\
\text { kewajibannya }\end{array}$ & $\begin{array}{l}\text { Membuktikan, } \\
\text { Memperluas } \\
\text { dan } \\
\text { memperdalam } \\
\text { data kuantitatif } \\
\end{array}$ \\
\hline $\begin{array}{l}3 \\
9\end{array}$ & $\begin{array}{ll}\text { Memiliki } \\
\text { motivasi } \\
\text { kerja untuk } \\
\text { mencapai } \\
\text { prestasi dan } \\
\text { penilaian } \\
\text { yang baik }\end{array}$ & $86,6 \%$ & $\begin{array}{l}\text { Guru memiliki motivasi kerja dan } \\
\text { prestasi yang tinggi }\end{array}$ & $\begin{array}{l}\text { Membuktikan, } \\
\text { Memperluas } \\
\text { dan } \\
\text { memperdalam } \\
\text { data kuantitatif }\end{array}$ \\
\hline $\begin{array}{l}4 \\
0\end{array}$ & \begin{tabular}{|l} 
Dapat \\
menyelesaik \\
an masalah \\
yang muncul \\
dalam proses \\
pembelajara \\
n berbasis \\
ICT
\end{tabular} & $79,7 \%$ & $\begin{array}{l}\text { Guru dapat menyelesaikan setiap } \\
\text { masalahnya dalam proses } \\
\text { pembelajaran berbasis ICT. }\end{array}$ & $\begin{array}{l}\text { Membuktikan, } \\
\text { Memperluas } \\
\text { dan } \\
\text { memperdalam } \\
\text { data kuantitatif }\end{array}$ \\
\hline $\begin{array}{l}4 \\
1\end{array}$ & \begin{tabular}{|l|} 
Mendapat \\
penghargaan \\
dalam setiap \\
prestasi kerja \\
\end{tabular} & $77,7 \%$ & $\begin{array}{l}\text { Kepala sekolah memberikan } \\
\text { penghargaan atas prestasi kerja } \\
\text { dalam setiap mata pelajaran }\end{array}$ & $\begin{array}{l}\text { Memperluas } \\
\text { dan } \\
\text { memperdalam } \\
\text { data kuantitatif }\end{array}$ \\
\hline $\begin{array}{l}4 \\
2\end{array}$ & $\begin{array}{l}\text { Memiliki hasil } \\
\text { karya sendiri } \\
\text { dalam ICT pada } \\
\text { pendidikan PAI } \\
\text { berbasis ICT }\end{array}$ & $75,4 \%$ & $\begin{array}{l}\text { Tidak semua guru memiliki hasil } \\
\text { karya dalam bidang PAI berbasis } \\
\text { ICT. }\end{array}$ & $\begin{array}{l}\text { Memperluas } \\
\text { dan } \\
\text { memperdalam } \\
\text { data kuantitatif }\end{array}$ \\
\hline $\begin{array}{l}4 \\
3\end{array}$ & $\begin{array}{l}\text { Pengembangan } \\
\text { hasil karya di } \\
\text { bidang } \\
\text { pendidikan } \\
\text { berbasis ICT } \\
\text { bernilai } \\
\text { Ekonomis }\end{array}$ & $76,7 \%$ & $\begin{array}{l}\text { Belum semua hasil karya guru dan } \\
\text { siswa bernilai ekonomis bagi } \\
\text { dirinya dan sekolah }\end{array}$ & $\begin{array}{l}\text { Memperluas } \\
\text { dan } \\
\text { memperdalam } \\
\text { data kuantitatif }\end{array}$ \\
\hline $\begin{array}{l}4 \\
4\end{array}$ & $\begin{array}{l}\text { Menciptakan } \\
\text { inovasi baru } \\
\text { dalam proses } \\
\end{array}$ & $73,4 \%$ & $\begin{array}{l}\text { Belum semua guru dan siswa } \\
\text { dapat mewujudkan inovasi terbaru } \\
\text { dalam proses pembelajaran }\end{array}$ & $\begin{array}{l}\text { Memperluas } \\
\text { dan } \\
\text { memperdalam } \\
\end{array}$ \\
\hline
\end{tabular}




\begin{tabular}{|l|l|l|l|l|}
\hline & $\begin{array}{l}\text { pembelajaran } \\
\text { PAI berbasis } \\
\text { ICT }\end{array}$ & berbasis ICT. & data kuantitatif \\
\hline 4 & $\begin{array}{l}\text { Mempublikasi } \\
\text { setiap hasil } \\
\text { karya dan } \\
\text { kegiatan } \\
\text { berbasis } \\
\text { ICT }\end{array}$ & $74,8 \%$ & $\begin{array}{l}\text { Mempublikasikan hasil karya } \\
\text { siswa dalam bidang ICT melalui } \\
\text { madding sekolah }\end{array}$ & $\begin{array}{l}\text { Memperluas } \\
\text { dan } \\
\text { memperdalam } \\
\text { data kuantitatif }\end{array}$ \\
\hline 4 & $\begin{array}{l}\text { Kualitaspendidi } \\
\text { kan agama } \\
\text { Islam berbasis } \\
\text { ICT secara } \\
\text { keseluruhan }\end{array}$ & & $\begin{array}{l}\text { Secara berangsur-angsur program } \\
\text { pendidikan berbasis ICT disekolah } \\
\text { tingkat SMP, SMA dan SMK } \\
\text { bertambah maju dengan kualitas/ } \\
\text { mutu pendidikan agama Islam } \\
\text { berbasis ICT secara keseluruhan } \\
\text { menunjukan peningkatan yang } \\
\text { baik. }\end{array}$ & $\begin{array}{l}\text { Memperluas } \\
\text { dan } \\
\text { memperdalam } \\
\text { data kuantitatif }\end{array}$ \\
& & &
\end{tabular}

Berdasarkan data tabel 4.12, dapat disimpulkan bahwa, kualitas pendidikan agama Islam berbasis ICT di sekolah Kota Gorontalo, secara keseluruhan menunjukkan hasil data yang berada pada posisi yang sangat baik.Data kuantitatif pada aspek konten kualitas pendidikan PAI berbasis ICT rata-rata nilai mencapai $85,5 \%$. Data kuantitatif ini diperluas dan diperdalam dengan data kualitatif yang menyatakan bahwa, kualitas pendidikan agama Islam berbasis ICT, ditinjau dari dimensi konteks memiliki visi dan misi, manajemen sekolah, serta peran semua steakholder disekolah baik orang tua, guru, pemerintahsecara bersama dalam melaksanakan proses pendidikan agama islam berbasis ICT secara baik dan benar, Dengan kerjasama dan dukungan yang baik, diharapkan peningkatkan kualitas pendidikan yang terlaksana secara propesional.Peningkatan kualitas pendidikan agama Islam berbasis ICT dipengaruhi oleh dimensi input, proses dan produk sebagai indicator yang harus dicapai dalam pengelolaan system pendidikan berbasis ICT.

Untuk mencetak proses pendidikan yang bermutu, setidaknya hal-hal yang harus menjadi pertimbangan sekolah dalam melaksanakan pendidikan diantaranya, bagaimana rekrutmen tenaga pendidiknya, kualifikasi pendidik, sarana dan prasarana serta kepribadian seorang pendidik yang propesional dalam upaya meningkatkan kualitas pendidikan di era MEA.Secara keseluruhan data kualitatif yang disajikan dalam tabel display data, dapat memperluas, memperdalm dan membuktikan data kuantitatif secara keseluruhan dengan nilia prosentase pada aspek konten, input, proses dan produk, mencapai rata-rata nilai $85 \%$ keatas, nilai ini secara kualitatif menerangkan data kualitas pendidikan agama islam berbasis ICT secara keseluruhan telah terpenuhi dan terlaksanakan dengan sangat baik di sekolah di Kota Gorontalo.

2) Variabel Persepsi guru PAI terhadap pendidikan agama Islam berbasis ICT diera MEA. 
Perbandingan data analisis kuantitatif dan kualitatif persepsi guru PAI terhadp pendidikan agama Islam berbasis ICT disajikan dalam tabel sebagai berikut:

Tabel 4.13: Perbandingan Data Kuantitatif Dan Kualitatif Variabel Persepsi guru PAI Terhadap Pendidikn agama Islam Berbasis ICT di era MEA.

\begin{tabular}{|c|c|c|c|c|}
\hline No & $\begin{array}{c}\text { Butir } \\
\text { Instrument/ } \\
\text { Kategori }\end{array}$ & $\begin{array}{c}\text { Data } \\
\text { Kuantitat } \\
\text { if (Nilai } \\
\% \text { \%) }\end{array}$ & Data Kualitatif & Kesimpulan \\
\hline 1 & Rasa ingin Tahu & $76,7 \%$ & $\begin{array}{l}\text { Mengetahui informasi } \\
\text { tentang maksud dari MEA. }\end{array}$ & $\begin{array}{l}\text { Memperluas } \\
\text { dan } \\
\text { memperdalam } \\
\text { data kuantitatif }\end{array}$ \\
\hline 2 & $\begin{array}{l}\text { Merasa tertarik } \\
\text { pada sesuatu }\end{array}$ & $81,3 \%$ & $\begin{array}{l}\text { Isu-isu dunia pendidikan } \\
\text { yang menarik dalam MEA } \\
\text { sekarang ini adalah } \\
\text { integrasi } \\
\text { pendidikan system } \\
\text { lapangan pekerjaan yang } \\
\text { dibutuhkan. }\end{array}$ & $\begin{array}{l}\text { Memperluas } \\
\text { dan } \\
\text { memperdalam } \\
\text { data kuantitatif }\end{array}$ \\
\hline 3 & $\begin{array}{l}\text { Memiliki } \\
\text { gagasan atas } \\
\text { perubahan }\end{array}$ & $80,7 \%$ & $\begin{array}{l}\text { Perubahan kebijakan dalam } \\
\text { dunia pendidikan saat ini } \\
\text { harus syarat dengan } \\
\text { pendidikan yang bermutu, } \\
\text { sesuai dengan kebutuhan } \\
\text { lapangan pekerjaan. }\end{array}$ & $\begin{array}{l}\text { Memperluas } \\
\text { dan } \\
\text { memperdalam } \\
\text { data kuantitatif }\end{array}$ \\
\hline 4 & $\begin{array}{l}\text { Sifat terbuka } \\
\text { pada perubahan } \\
\text { kebijakan }\end{array}$ & $75,7 \%$ & $\begin{array}{l}\text { Seluruh guru harus siap } \\
\text { menerimar perubahan } \\
\text { tersebut, dengan cara yang } \\
\text { harus dilakukan } \\
\text { diantaranya dengan } \\
\text { meningkatakan kompetensi } \\
\text { keilmuan, meningkatkan } \\
\text { kemampuan dalam bidang } \\
\text { ICT, selalu mengupdate } \\
\text { perubahan-perubahan } \\
\text { informasi, dan siap } \\
\text { menerima persaingan } \\
\text { dengan tenaga kerja luar. }\end{array}$ & $\begin{array}{l}\text { Memperluas } \\
\text { dan } \\
\text { memperdalam } \\
\text { data kuantitatif }\end{array}$ \\
\hline 5 & $\begin{array}{l}\text { Mencoba hal-hal } \\
\text { yang baru yang } \\
\text { dijumpai dalam } \\
\text { pendidikan }\end{array}$ & $83,3 \%$ & $\begin{array}{l}\text { Mengembangkan } \\
\text { propesionalitas dalam } \\
\text { pendidikan. Guru-guru } \\
\text { mampu menyesuaikan diri } \\
\text { dan berani mencoba } \\
\text { sesuatu hal yang baru. }\end{array}$ & $\begin{array}{l}\text { Memperluas } \\
\text { dan } \\
\text { memperdalam } \\
\text { data kuantitatif }\end{array}$ \\
\hline 6 & Intropeksi diri & $88,5 \%$ & mengatasi & Memperluas \\
\hline
\end{tabular}




\begin{tabular}{|c|c|c|c|c|}
\hline & $\begin{array}{l}\text { dan } \\
\text { memposisikan } \\
\text { diri }\end{array}$ & & $\begin{array}{l}\text { kekurangan dan } \\
\text { memanfaatkan kelebihan } \\
\text { yang dimiliki guru, maka } \\
\text { harus lebih banyak } \\
\text { memperbaharui } \\
\text { pengetahuan dengan selalu } \\
\text { memperbaharui informasi } \\
\text { tentang pendidikan dan } \\
\text { perubahan jaman. }\end{array}$ & $\begin{array}{l}\text { dan } \\
\text { memperdalam } \\
\text { data kuantitatif }\end{array}$ \\
\hline 7 & $\begin{array}{l}\text { Dapat } \\
\text { menyelesaikan } \\
\text { masalah yang } \\
\text { sulit }\end{array}$ & $80,3 \%$ & $\begin{array}{l}\text { Menyelesaikan } \\
\text { permasalahan- } \\
\text { permasalahan yang muncul } \\
\text { dalam perkembangan } \\
\text { pendidikan di MEA dengan } \\
\text { selalu mengupayakan dan } \\
\text { mengikuti perkembangan } \\
\text { untuk meningkatkan mutu } \\
\text { pendidikan dalam } \\
\text { kurikulum berdasarkan } \\
\text { standar nasional yang } \\
\text { diterapkan disekolah. }\end{array}$ & $\begin{array}{l}\text { Memperluas } \\
\text { dan } \\
\text { memperdalam } \\
\text { data kuantitatif }\end{array}$ \\
\hline 8 & $\begin{array}{l}\text { Prediksi } \\
\text { terhadap } \\
\text { perubahan } \\
\text { mental guru dan } \\
\text { siswa dalam } \\
\text { pendidikan } \\
\text { berbasis ICT di } \\
\text { era MEA ini. }\end{array}$ & $80,0 \%$ & $\begin{array}{l}\text { Perubahan mental secara } \\
\text { positif dengan perubahan } \\
\text { jaman sekarang ini, mental } \\
\text { akan berubah sehingga } \\
\text { guru dituntut terus untuk } \\
\text { memahami komptensi } \\
\text { pribadi, pendagogik dan } \\
\text { keterampilannya dalam } \\
\text { pendidikan. perubahan } \\
\text { mental secara negatif guru } \\
\text { dan siswa yang tidak } \\
\text { memiliki kompetensi akan } \\
\text { kehilangan lapangan } \\
\text { pekerjaan. }\end{array}$ & $\begin{array}{l}\text { Memperluas } \\
\text { dan } \\
\text { memperdalam } \\
\text { data kuantitatif }\end{array}$ \\
\hline 9 & $\begin{array}{l}\text { Persaingan } \\
\text { lapangan } \\
\text { pekerjaan di } \\
\text { MEA }\end{array}$ & $84,3 \%$ & $\begin{array}{lr}\text { Persaingan } & \text { lapangan } \\
\text { pekerjaan yang dihadapi } \\
\text { oleh tenaga kerja Indonesia } \\
\text { khususnya guru dan siswa } \\
\text { serta tenaga kependidikan } \\
\text { adalah } & \text { memiliki } \\
\text { kompetensi pendidikan } \\
\text { yang unggul, memiliki } \\
\text { keterampilan } \\
\text { berbasis ICT, dan yang } \\
\text { terpenting }\end{array}$ & $\begin{array}{l}\text { Memperluas } \\
\text { dan } \\
\text { memperdalam } \\
\text { data kuantitatif }\end{array}$ \\
\hline
\end{tabular}




\begin{tabular}{|c|c|c|c|c|}
\hline & & & $\begin{array}{lr}\text { menyesuikan diri } & \text { dengan } \\
\text { perkembangan } & \text { dunia } \\
\text { pendidikan saat ini. } & \end{array}$ & \\
\hline 10 & $\begin{array}{l}\text { Harapan dalam } \\
\text { pendidikan } \\
\text { berbasis ICT di } \\
\text { MEA }\end{array}$ & $77,4 \%$ & $\begin{array}{l}\text { Harapan dalam pendidikan } \\
\text { di Indonesia saat ini, } \\
\text { khususnya di daerah Kota } \\
\text { Gorontalo, pemerintah } \\
\text { mampu untuk menunjang } \\
\text { penyelenggaraan } \\
\text { pendidikan disekolah } \\
\text { dengan melengkapi seluruh } \\
\text { kebutuhan/ fasilitas sarana } \\
\text { sekolah terutama untuk } \\
\text { brand pendidikan berbasis } \\
\text { ICT. }\end{array}$ & $\begin{array}{l}\text { Memperluas } \\
\text { dan } \\
\text { memperdalam } \\
\text { data kuantitatif }\end{array}$ \\
\hline 11 & $\begin{array}{l}\text { Bayangan } \\
\text { pendidikan yang } \\
\text { sesuai dengan } \\
\text { perkembangan } \\
\text { siswa dan guru } \\
\text { di daerah } \\
\text { Gorontalo } \\
\text { menghadapi } \\
\text { MEA }\end{array}$ & $79,0 \%$ & $\begin{array}{l}\text { Untuk daerah Gorontalo, } \\
\text { pendidikan disesuaikan } \\
\text { dengan budaya dan kultur } \\
\text { yang berada di masyarakat. } \\
\text { Tentunya dengan tidak } \\
\text { menafikan sesuatu yang } \\
\text { dapat mengembangkan dan } \\
\text { memajukan } \\
\text { pendidikan dalam } \\
\text { penggunaan ICT dalam } \\
\text { pendidikan. }\end{array}$ & $\begin{array}{l}\text { Memperluas } \\
\text { dan } \\
\text { memperdalam } \\
\text { data kuantitatif }\end{array}$ \\
\hline 12 & $\begin{array}{l}\text { Berani } \\
\text { menghadapi } \\
\text { resiko, siap } \\
\text { dikritik dan } \\
\text { tidak takut gagal } \\
\text { sebagai dampak } \\
\text { atas munculnya } \\
\text { pendidikan di } \\
\text { era MEA }\end{array}$ & $75,7 \%$ & $\begin{array}{l}\text { Menghadapi pendidikan di } \\
\text { MEA, rasa takut akan } \\
\text { kehilangan pekerjaan dan } \\
\text { tidak mendapatkan posisi } \\
\text { yang baik dalam pekerjaan } \\
\text { harus di singkirkan, harus } \\
\text { bersikap luwes menerima } \\
\text { kritikan dan resiko apapun } \\
\text { yang terjadi. Dampak yang } \\
\text { akan dirasakan dalam } \\
\text { pendidikan adalah } \\
\text { perkembangan pendidikan } \\
\text { didaerah maju akan } \\
\text { semakin baik dan untuk } \\
\text { daerah yang tertinggal, } \\
\text { pendidikan tidak } \\
\text { mengalami perubahan } \\
\text { sama sekali tertinggal } \\
\text { dengan yang lainnya. }\end{array}$ & $\begin{array}{l}\text { Memperluas } \\
\text { dan } \\
\text { memperdalam } \\
\text { data kuantitatif }\end{array}$ \\
\hline 13 & Meningkatkan & $79,0 \%$ & Mengatasi ketertinggalan & Memperluas \\
\hline
\end{tabular}




\begin{tabular}{|c|c|c|c|c|}
\hline & $\begin{array}{l}\text { kompetensi dan } \\
\text { keterampilan } \\
\text { kinerja dalam } \\
\text { pendidikan di } \\
\text { MEA }\end{array}$ & & 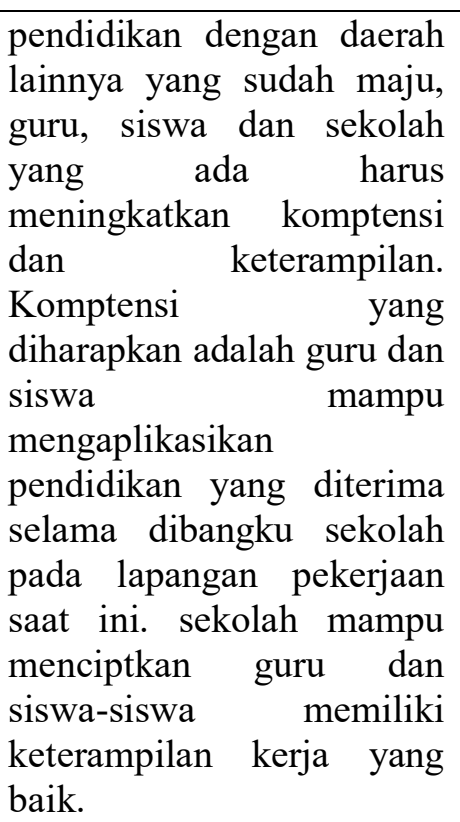 & $\begin{array}{l}\text { dan } \\
\text { memperdalam } \\
\text { data kuantitatif }\end{array}$ \\
\hline 14 & $\begin{array}{l}\text { Pendekatan- } \\
\text { pendekatan yang } \\
\text { dikukan dalam } \\
\text { meningkatkan } \\
\text { kompetensi dan } \\
\text { keterampilan } \\
\text { kinerja dalam } \\
\text { MEA. }\end{array}$ & $85,9 \%$ & $\begin{array}{l}\text { Pendekatan-pendekatan } \\
\text { dalam pendidikan yang } \\
\text { harus dilakukan } \\
\text { diantaranya adalah } \\
\text { pendidikan produktif bagi } \\
\text { siswa artinya pendidikan } \\
\text { yang diterima secara } \\
\text { langsung dapat } \\
\text { dipraktekkan dan dapat } \\
\text { menciptakan suatu produk } \\
\text { yang bermanfaat bagi siswa } \\
\text { dan siswi, yang berasosiasi } \\
\text { dengan produk di era MEA } \\
\text { sekarang ini. }\end{array}$ & $\begin{array}{l}\text { Memperluas } \\
\text { dan } \\
\text { memperdalam } \\
\text { data kuantitatif }\end{array}$ \\
\hline 15 & $\begin{array}{l}\text { Kompetensi } \\
\text { seorang guru } \\
\text { dalam } \\
\text { pendididikan di } \\
\text { era MEA }\end{array}$ & $84,6 \%$ & $\begin{array}{l}\text { Kompetensi pendidikan } \\
\text { yang harus dimiliki oleh } \\
\text { seorang guru di MEA, } \\
\text { diantaranya adalah guru } \\
\text { harus memiliki kompetensi } \\
\text { pendagogik, propesional, } \\
\text { kepribadian } \\
\text { kompetensi sosial. }\end{array}$ & $\begin{array}{l}\text { Memperluas } \\
\text { dan } \\
\text { memperdalam } \\
\text { data kuantitatif }\end{array}$ \\
\hline 16 & $\begin{array}{l}\text { Terikat dengan } \\
\text { budaya, agama, } \\
\text { dan karakter } \\
\text { masyarakat. }\end{array}$ & $83,3 \%$ & $\begin{array}{l}\text { Budaya, social, pendidikan } \\
\text { di MEA mengalami } \\
\text { alkulturasi r budaya } \\
\text { pendidikan dengan Negara } \\
\text { lain. Namun diharapkan } \\
\text { nilai-nilai budaya lokal, }\end{array}$ & $\begin{array}{l}\text { Memperluas } \\
\text { dan } \\
\text { memperdalam } \\
\text { data kuantitatif }\end{array}$ \\
\hline
\end{tabular}




\begin{tabular}{|c|c|c|c|c|}
\hline & & & $\begin{array}{l}\text { agama, dan tradisi/ adat } \\
\text { istiadat masyarakat } \\
\text { setempat harus terjaga dan } \\
\text { terus untuk dilestarikan } \\
\text { guna mengikis budaya- } \\
\text { budaya yang tidak cocok } \\
\text { untuk siswa-siswa didaerah } \\
\text { Gorontalo. }\end{array}$ & \\
\hline 17 & $\begin{array}{l}\text { Secara } \\
\text { keseluruhan } \\
\text { pendidikan } \\
\text { agama Islam } \\
\text { berbasis ICT } \\
\text { dapat menjawab } \\
\text { tantangan di era } \\
\text { pendidikan } \\
\text { MEA }\end{array}$ & $81,0 \%$ & $\begin{array}{l}\text { Secara } r \text { keseluruhan } \\
\text { perpektif yang diharapkan } \\
\text { dari guru PAI semakin } \\
\text { meningkat } \\
\text { tanggapan yang tengan } \\
\text { dalam model pendidikan di } \\
\text { MEA sekarang ini, dengan } \\
\text { mewujudkan pendidikan } \\
\text { agama Islam berbasis ICT } \\
\text { sebagai jawaban atas model } \\
\text { pendidikan di era MEA. }\end{array}$ & $\begin{array}{l}\text { Membuktikan, } \\
\text { Memperluas } \\
\text { dan } \\
\text { memperdalam } \\
\text { data kuantitatif }\end{array}$ \\
\hline
\end{tabular}

Berdasarkan analisis data pada tabel 4.13 tersebut, pada dimensi rasa ingin tahu guru mendapatkan nilai 76,7\%. Data kuantitatif ini diperluas dan diperdalam dengan data kualitatif yang menyatakan bahwa guru PAI mengetahui informasi tentang MEA melalui media massa dan sosial serta guru mengetahui maksud dari adanya MEA, dengan adanya pembentukan pasar global dalam bidang ekonomi di negara-negara ASEAN, rasa ingin tahu ini menunjukkan ketertarikan guru terhadap sesuatu yang muncul di MEA khususnya dalam dunia pendidikan, hal ini dapat dilihat dari nilai yang diperoleh pada data kuantitatif $=81,3 \%$. Selanjutnya untuk mengetahui bagaimana tantangan yang akan dihadapi oleh guru dalam MEA. Data kualitatif memperdalam data kuantitatif dengan menyatakan bahwa dalam pendidikan berbasis ICT di era MEA, guru harus memiliki gagasan dan ideide yang baru, mau mencoba sesuatu dengan tekun, memiliki kompetensi yang tinggi, memiliki sikap terbuka, mau menerima perubahan dan kebijakan yang terjadi dalam dunia pendidikan, selalu melakukan intropeksi diri dan mampu memposisikan diri, serta dapat menyelesaikan permasalahan yang muncul, tidak takut menerima resiko dan siap dikritik demi kemajuan pendidikan. Semua indikator dalam persepsi guru PAI terhadap pendidikan agama Islam berbasis ICT, memperdalam dan memperluas data kuantitatif dengan taraf nilai yang diperoleh pada data kuantitatif sebesar $75 \%$ sampai dengan- $88 \%$ pada posisi yang baik.

Berdasarkan hasil penelitian dan pengelolahan data tentang persepsi guru PAI terhadap pendidikan agama Islam berbasis ICT di era MEA, secara keseluruhan memiliki kategori yang baik. Guru PAI memberikan dukungan terhadap perubahan dan kebijakan pendidikan dengan system pendidikan berbasis ICT dengan persepsi yang menyatakan bahwa dalam pendidikan agama Islam berbasis ICT diera MEA, hal-hal yang menjadi faktor pendukung yang harus 
dimiliki oleh guru PAI yaitu; (1) bagaimana rasa ingin tahu, (2) merasa tertarik, memiliki sikap terbuka,(3) mau mencoba hal yang baru, (4) tidak takut tantangan, (5) berani menerima segala resiko dan siap untuk dikritik, dan (6) selalu untuk meningkatkan kompetensi dan keterampilan dalam kinerja, (7) Secara mental tidak mudah untuk terpengaruh dengan budaya luar yang tidak cocok dengan tradisi masyarakat setempat atau merasa terikat dengan budaya lokal, social, agama dan karekater masyarakat setempat.

Analisis pada aspek ini secara keseluruhan menyatakan bahwa persepsi guru PAI dalam pendidikan berbasis ICT secara signifikansinya mempengaruhi, sikap dan prilaku orang, budaya, social, agama dan karakter suatu bangsa dalam meningkatkan kualitas pendidikan khususnya pedidika di era MEA saat ini.

\section{b. Analisis Hubungan Antar Variabel Kuantitatif dan Kualitatif.}

Untuk mengembangkan indikator dan menemukan varian yang saling behubungan antar variabel dalam penelitian ini, maka dilakukan analisis hubungan anatar variabel berdasarkan hasil wawancara terstruktur dengan informan yang diperaya, disajikan dalam bentuk tabel sebagai berikut:

Tabel 4.14: Data Kuantitatif Dan Kualitatif Hubungan Antara Variabel

\begin{tabular}{|c|c|c|c|c|}
\hline No & $\begin{array}{c}\text { Hubungan } \\
\text { antar Variabel }\end{array}$ & $\begin{array}{c}\text { Data } \\
\text { Kuanti } \\
\text { tatif } \\
(\text { Nilai } \\
\%) \\
\end{array}$ & Data Kualitatif (hubungan) & $\begin{array}{l}\text { Kesimpul } \\
\text { an }\end{array}$ \\
\hline 1 & $\begin{array}{l}\text { Persepsi guru } \\
\text { PAI terhadap } \\
\text { pendidikan } \\
\text { agama Islam } \\
\text { berbasis ICT } \\
\text { berpengaruh } \\
\text { terhadap } \\
\text { peningkatan } \\
\text { kualitas } \\
\text { pendidikan } \\
\text { agama islam } \\
\text { Berbasis ICT } \\
\text { disekolah di } \\
\text { Kota Gorontalo. }\end{array}$ & 0,986 & $\begin{array}{l}\text { Persepsi guru PAI terhadap } \\
\text { pendidikan agama Islam berbasis } \\
\text { ICT merupakan varian yang } \\
\text { menentukan peningkatan kualitas } \\
\text { pendidikan disekolah kota } \\
\text { Gorontalo. Hubungan ini terjadi } \\
\text { dengan sangat kuat dikarenakan, } \\
\text { Keberhasilan kualitas pendidikan } \\
\text { berbasis ICT dapat diukur } \\
\text { berdasarkan proses yang } \\
\text { dilakukan disekolah yang ditinjau } \\
\text { dari dimensi konten, input, proses } \\
\text { dan produk yang ditawarkan oleh } \\
\text { pihak sekolah sebagai suatu } \\
\text { sistem pelayanan pendidikan yang } \\
\text { bermutu saat ini. }\end{array}$ & $\begin{array}{l}\text { Memperlu } \\
\text { as dan } \\
\text { memperda } \\
\text { lam data } \\
\text { kuantitatif }\end{array}$ \\
\hline
\end{tabular}

\section{Penutup}

1. Secara kuantitatif kualitas pendidikan agama Islam berbasis ICT yang ada di Kota Gorontalo diperoleh harga porsentase sebesar $=85,6 \%$. Hal ini berarti kualitas pendidikan agama Islam berbasis ICT yang diselenggarakan disekolah Kota Gorontalo terlaksana secara sangat baik. Harga porsentase ini melebihi 
skor nilai yang dihipotesiskan sebesar $80 \%$, dengan harga uji signifikan menggunakan uji-t sebesar $=72 \%$.

2. Secara kualitatif kualitas pendidikan agama Islam berbasis ICT dinyatakan sangat baik. Tidak terdapat perbedaan antara data kuantitatif dan data kualitatif tentang kualitas pendidikan agama Islam berbasis ICT di Kota Gorontalo. Secara keseluruhan kualitas pendidikan agama Islam berbasis ICT di Kota Gorontalo mengalami peningkatan dan perkembangan yang sangat baik. Peningkatan kualitas pendidikan agama berbasis ICT di Kota Gorontalo, dilakukan secara profesional, dengan memperhatikan dan melaksanakan seluruh manajemen sekolah dalam pengelolaan pendidikan berbasisi ICT, mulai dari pelaksanaan visi dan misi pendidikan, masalah pembiayaan dan standar operasional pendidikan sekolah yang berkualitas, serta seluruh aspek input, proses dan produk yang menjadi ukuran dalam peningkatan kualitas pendidikan berbasis ICT.

3. Secara kuantitatif persepsi guru PAI terhadap pendidikan agama Islam berbasis ICT diperoleh harga porsentase sebesar $=80,9 \%$. hal ini berarti persepsi guru PAI terhadap kualitas pendidikan agama Islam berbasis ICT disekolah Kota Gorontalo tergolong baik. Harga porsentase ini melebihi skor nilai yang dihipotesiskan sebesar $70 \%$, dengan harga uji signifikan menggunakan uji-t sebesar $=11,92 \%$.

4. Secara kualitatif, persepsi guru PAI terhadap pendidikan agama Islam berbasis ICT di Kota Gorontalo dinyatakan baik. Dengan demikian data kualitatif mendukung data kuantitatif, karena tidak terjadi perbedaan antara data kuantitatif dan data kualitatif secara hirarki dalam persepsi guru PAI yang muncul dari sikap dan pengetahuan dalam merespon pendidikan agama Islam berbasis ICT diera MEA saat ini. Persepsi guru PAI terhadap pendidikan agama Islam berbasis ICT secara keseluruhan memberikan pandangan yang baik pada pendidikan agama Islam berbasis ICT sebagai upaya dalam meningkatkan pendidikan agama Islam di era MEA. Persepsi guru PAI tercermin melalui sikap dan pengetahuan guru yang mau menerima tantangan, memiliki rasa ingin tahu yang kuat, memiliki imajinatif dan inovatif dalam pendidikan serta memiliki sikap intelektual, mau berpikir luwes, terperinci, dan kolaboratif dalam perubahan pendidikan menuju kearah yang lebih baik, dalam merespon seluruh aktivitas dunia pendidikan berbasis ICT yang terjadi dalam MEA. Hasil penelitian kualitatif ini, memperkuat, memperdalam dan memperluas hasil penelitian kauntitatif tentang persepsi guru PAI terhadap pendidikan agama Islam berbasis ICT di Kota Gorontalo.

5. Terdapat hubungan yang sangat kuat antara persepsi guru PAI terhadap pendidikan agama Islam berbasis ICT dengan kualitas pendidikan agama Islam berbasis ICT di era MEA. Dengan nilai kontribusi sebesar 98,6 \%, dan $1,4 \%$ kualitas pendidikan ditentukan oleh faktor lain seperti motivasi dan model kinerja (teori belajar). Dari persamaan regresi linear $\mathrm{Y}=63,547$ (a) $+0,27$ (b). $\mathrm{X}$, dengan taraf siginifikansi 0,05\%. Dapat diinterpretasikan bahwa setiap kenaikan satu unit skor persepsi guru PAI terhadap pendidikan agama Islam berbasis ICT akan diikuti oleh kenaikan $0,27 \%$ hasil kualitas pendidikan agama Islam berbasis ICT diera MEA. 
Artinya bila persepsi guru PAI terhadap pendidikan agama Islam berbasis ICT meningkat maka kualitas pendidikan pun akan meningkat begitu sebaliknya.

6. Secara kualitatif hasil penelitan memperkuat, memperdalam dan memperluas data kuantitatif dengan korelasi yang terjadi sebesar $=0,993$. Data kualitatif memperdalam memperkuat, dan membuktikan bahwa persepsi guru PAI terhadap pendidikan agama Islam berbasis ICT merupakan salah satu varian yang dapat menentukan kualitas pendidikan agama Islam berbasis ICT diera MEA. Secara keseluruhan hasil penelitian tentang persepsi guru PAI terhadap pendidikan agama Islam berbasis ICT diera MEA mendorong guru PAI untuk meningkatkan, kualitas pendidikan, secara propesional dengan kompetensi dan keterampilan berbasis ICT yang baik.

\section{DAFTAR PUSTAKA}

Abdullah, M. Yatimin. Studi Islam Kontemporer, Jakarta: Amza, 2006

Arikunto, Suharsimi, Penilaian Program Pendidikan, Jakarta: Gramedia Pustaka Utama, Tahun 2001.

Amrullah, M. Amin. Panduan menyusun Proposal Skripsi Tesis dan Disertasti. Yogyakarta: Smart Pustaka, 2014

Abdullah, Gamar dan Walangadi, Hakop. "Pengembangan Model Pembelajaran Berbasis IT Yang Terintegrasi Pembelajaran Budaya Dan Karakterbangsa Di Jurusan Pendidikan Sekolah Dasar" Laporan Gorontalo: Jurusan Pendidikan Guru Sekolah Dasar Fakultas Ilmu Pendidikan Universitas Negeri Gorontalo Tahun, 2014

Abdul Rahmat, dkk. Manajemen Pendidikan Oreintasi Mutu, Teori dan Implementasi pada Aras Lokal. Gorontalo: Ideas Publishing, 2013

Budiyanto, H. Mangun. Ilmu pendidikan Islam, Yogyakarta: Penerbit Ombak, 2013.

Budi, Ibrahim, Total Quality Management: Panduan Untuk Menghadapi Persaingan Global, Jakarta: Djambatan, 2000.

Cortada, J.W, Total Quality Management edisi Indonesia,Yogyakarta; Andi, 1996.

Direktorat kerjasama ASEAN, Kementerian Luar Negeri Republik Indonesia, Cetak Biru Komunitas Sosial Budaya (Socio-Cultural Community Blueprint), Jakarta, 2010.

Daulah, Haidar Putra dan Nurgaya Pasa, Pendidikan Islam Dalam Mencerdaskan Bangsa, Jakarta: Rineka Cipta, 2012.

Daradjat, Zakiyah, Ilmu Pendidikan Islam, Jakarta; Bumi Aksara, 1996.

Dimyati. “AktivitasBelajar”.www/ http:// aktivitas belajar.ac.id/disertasi article/view. Diaskses 12 Maret 2016.

Dalie, Novita."Fungsi Perencanaan Pendidikan dalam Rangka Peningkatan Mutu Sekolah”.Tesis. Jakarta: Program Pasca Sarjana Universitas Negeri Jakarta (UNJ), 2006. 
Dacholfany, M. Ihsan." Reformasi Pendidikan Islam Menghadapi Era Globalisasi Sebuah Tantangan Dan Harapan”. Jurnal AKADEMIKA, Vol. 20, No. 01 Januari - Juni 2015. (diakses 04 November 2015).

Eko,Putro, Widoyoko, Analisis pengaruh kinerja Guru terhadap motivasi belajar siswa, Porwokerto, 2008

Getteng, Abd Rahman. Menuju Guru Propesional dan Beretika. Yogyakarta: Graha Guru, 2009.

Ibrahim, Husni, Arah baru Pendidikan Islam di Indonesia, Jakarta: PT Logos Wacana Ilmu, 2001.

Rohmah, Mamah Siti "Pendidikan Agama Islam dam Setting Pendidikan Inklusi" Tesis Jakarta: Pascasarjana Ilmu Pendidikan Islam Unversitas Islam Syarif Hidayatullah Tahun, 2010.

Ridwan, Belajar Mudah Penelitian Untuk Guru,Karyawan Dan Peneliti Muda, Bandung: Alfabeta, 2013.

Rusman, Model-Model Pembelajaran Mengembangkan Profesionalisme Guru.Jakarta: PT. Raja Grafindo Jakarta, 2013.

Stuffebeam, D.L. Educational Evaluation And Decision Making, 1971\&Shinkfield. A.J Systematic Evaluation/, Boston, Kluwer Nijhob Publishing, 2005

Johnson, Lou Anne. Teaching Outside the Box: How to Grab Your Student by Their Brains, diterjemahkan oleh Dani Dharyani dengan judul Pengajaran Yang Kreatif Dan Menarik Cara Membangkitkan Minat Siswa Melalui Pemikiran. Jakarta: PT Macanan Jaya Cemerlang, 2009.

Kardinata, Sunaryo. Isu-Isu Pendidikan: Antara Harapan Dan Kenyataan, Bandung: UPI PRESS, 2010.

Kadir, Syaiful "Gaya Kepemimpinan Kepala Sekolah Berorientasi Budaya Mutu” Sinopsi doktor, Gorontalo: Ideas Publishing, 2013.

ngiu, Zulacha, "Evaluasi kebijakan penjamin mutu di perguruan tinggi,"Sinopsis para alumni doctor dalam buku "Gorontalo: Ideas publishing, 2013

Munandar, Sc. Utami. Mengembangkan Bakat Dan Kreativitas Anak Sekolah Petujuk Bagi Guru Dan Orang Tua. Jakarta: PT Gramedia Widiasarana Indonesia, 2000

Madjid, Nurcholish, Pendidikan Agama Dan Akhlak Bagi Anak Dan Remaja" Pendidikan Agama Dalam Rumah Tangga Bagi Pertumbuhan Anak Saleh" Jakarta: Logos,2001.

Muhaimin, dkk, Pengembangan Kurikulum Pendidikan Agam Islam Disekolah, Madrasah Dan Perguruan Tinggi, Jakarta: Raja Grafindo Persada, 2005

Mulyasa. Manajemen Berbasis Sekolah, Bandung : Ramaja Rosdakarya, 2002.

Nahlawi, an-Abd, "Usulu Atarbiyatul Islamiyah Waasalibuha, Damsyik: Darul Fikri 1979)

Sallis, Edward, Total Quality Manajement, London: Phyladelphy, 1993.

Sadbudhy Rahayu, Endang dan Nuryata, I Made. Pengembangan Soft Skills. Jakarta: Sekarmita, 2011

Somantri, T.Sutjihati. Psikologi Anak Luar Biasa. Bandung: PT.Refika Aditama, 2007. 
Sulaiman, Wahid, Jalan pintas menguasai SPSS 10.Yokyakarta: Andi 2002.

Sugiyono. Metode Penelitian Pendidikan Pendekatan Kuantitatif, Kualitatif, dan $R \& D$. Bandung: Alfabeta, 2014.

Sugiyono.Metode Penelitian Kombinasi(Mixed Methods) Bandung: Alfabeta, 2014.

Sarwono, Jonathan. Mixed Methodes Cara Menggabung Riset Kuantitatif dan Kualitatif secera Benar. Jakarta: Pt. Elex Media Koputindo, 2011.

Uno, B. Hamzah. Variabel Penelitian dalam Pendidikan dan Pembalajaran. Jakarta: PT Ina Publikatama, 2014.

Uno, B. Hamzah. Oreintasi Baru dalam Psikologi Pembelajaran. Jakarta: Bumi Aksara, 2012.

Uno, B. Hamzah Dan Lamatenggo Nita, Teknologi Dan Komunikasi Pembelajaran, Jakarta: PT Bumi Aksara, 2010.

-------------Undang-Undang Dan Peraturan Pemerintah Ri Tentang Pendididkan, Jakarta : Direktorat Jenderal Pendidikan Islam Departemen Agama RI, Tahun 2006.

Ilmu dan Teknologi dalam Islam, Jakarta: Terbitan Departemen Agama RI, 2005.

Kendali Mutu Pendidikan Agama Islam, Jakarta: Direktorat Jenderal Pembinaan Kelembagaan Agama Islam, Tahun 2001.

------------ Cetak Biru Komunitas Social Budaya (Socio-Cultural Community Blue Print) Asean, Direktorat Jenderal Kerjasama ASEAN Kementerian Luar Negeri Republik Indonesia, Jakarta: 2010.

$\mathrm{http} / / \mathrm{www}$. Infed.org/ mobi/what-is-education-a definition-and discussion). (Diakses 25 maret 2016)

http://tokobukuadm.com/artikel/duniapendidikandanmasyarakatekonomiasean

http://bisnis.tempo.co/read/news/2015/09/25/090703924/duniapendidikanperlusad arsertifikasihadapimea. (Diakses 8 April 2016)

http://panjimas.com/citizens/2015/10/23/pentingnyapendidikanislamdalamhadapi mea(Diakses 10April 2016)

http://www.kompasiana.com/wisnuandangjaya/meadanpendidikanyangberkualitas 55530d2db67e611308130970 (Diakses 10 april 2016)

http://www.bbc.com/indonesia/berita indonesia/2014/08/140826 pasar tenaga k erja_aec (Diakses 10 April 2016) 